\title{
DifFICULT OF AMENDMENT AND INTERPRETATIVE CHOICE
}

\author{
ANDREW COAN ${ }^{\dagger}$ \\ ANUJ DESAI ${ }^{\dagger \dagger}$
}

\begin{abstract}
The extreme difficulty of amending the U.S. Constitution plays a central but largely unexamined role in theoretical debates over interpretive choice. In particular, conventional wisdom assumes that the extreme difficulty of Article $\mathrm{V}$ amendment weakens the case for originalism. This view might ultimately be correct, but it is not the freestanding argument against originalism it is often presumed to be. Rather, it depends on contestable normative and empirical premises that require defense. If those premises are wrong, the stringency of Article $\mathrm{V}$ might actually strengthen the case for originalism. Or Article V might have no impact on that case one way or another. This "complexity thesis" highlights and clarifies the role that difficulty of amendment plays across a range of significant interpretive debates, including those surrounding writtenness, John Hart Ely's representation-reinforcement theory, interpretive pluralism, and originalism as a theory of positive law. It also has important implications for the under-studied relations between statutory and constitutional interpretation and federal and state constitutional interpretation.
\end{abstract}

KEYWORDS: Interpretive Choice; Constitutional Amendment; Constitutional Interpretation; Statutory Interpretation; Originalism.

\footnotetext{
† Professor, James E. Rogers College of Law, University of Arizona, USA.

$\Uparrow$ Professor, Law School, University of Wisconsin, USA.
} 
RESUMO: A extrema dificuldade de emendar a Constituição dos Estados Unidos desempenha em um papel central, mas largamente não examinado, nos debates teóricos sobre escolha interpretativa. Em particular, a sabedoria convencional assume que a extrema dificuldade de emendar do Artigo V enfraquece o argumento do originalismo. Essa visão pode estar, definitivamente, correta, mas não é o argumento autônomo contra o originalismo que, frequentemente, presumem ser. Ao contrário, isso depende de premissas normativas e empíricas contestáveis que requerem defesa. Se aquelas premissas estiverem erradas, o rigor do Artigo $\mathrm{V}$ pode, na verdade, fortalecer o argumento do originalismo. Ou o Artigo $\mathrm{V}$ pode não ter influência sobre o argumento de modo algum. Essa "teoria da complexidade" destaca e esclarece o papel que aquela dificuldade para emendar desempenha através de uma série de significativos debater interpretativos, incluindose aqueles ao redor de literalidade, teoria do reforço da representação de John Hart Ely, pluralismo interpretativo e originalismo enquanto uma teoria do direito positivo. Isso também importantes implicações para as negligenciadas relações entre interpretações judicial e constitucional e entre interpretação de Constituições Federal e Estaduais.

PALAVRAS-CHAVE: Escolha Interpretativa; Emendas Constitucionais; Interpretação Constitucional; Interpretação Jurídica; Originalismo. 


\section{TABLE OF CONTENTS:}

I. INTRODUCTION...........................................................................................205

II. INTRODUCING THE COMPLEXITY THESIS.......................................209

1. The Conventional View.............................................................210

2. The Complexity Thesis ...........................................................212

3. The Voting-Rules Literature ...............................................216

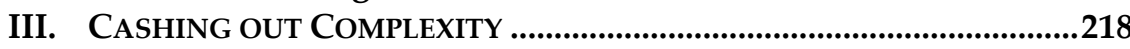

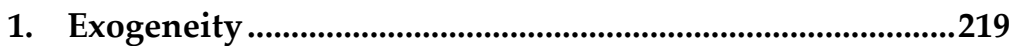

1.1. Exogenous Arguments for Originalism...........................219

1.2. Exogenous Arguments for Nonoriginalism .....................223

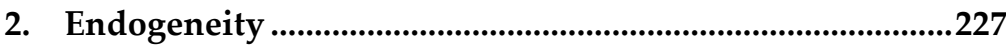

2.1. Endogenous Arguments for Nonoriginalism ...................228

2.2. Endogenous Arguments for Originalism ........................231

2.3. Aziz Huq's Two-Speed Constitution ................................234

3. Summing Up...................................................................................235

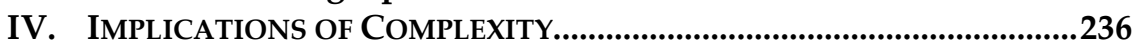

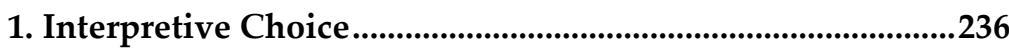

1.1. Difficulty of Amendment and Exogenous Arguments ....237

1.2. Difficulty of Amendment and Endogenous Arguments ..238

1.3. Exogenous vs. Endogenous Arguments ..........................239

2. Statutory vs. Constitutional Interpretation ............................240

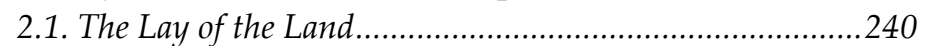

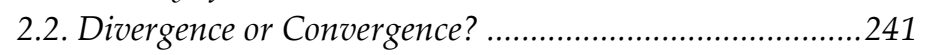

2.3. The Complexity Thesis Applied .......................................244

3. State vs. Federal Constitutional Interpretation .....................247

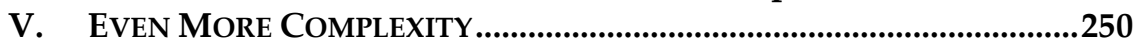

1. Institutional Assumptions ........................................................251

2. Comparative Institutional Competence.................................253

3. The Impact of Interpretive Choice on Difficulty of ................

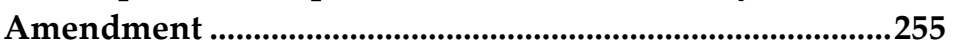

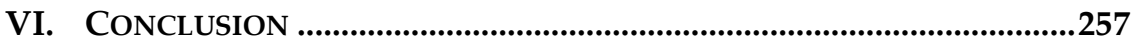

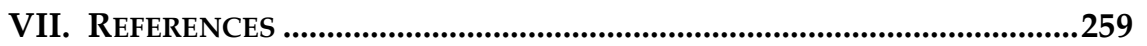




\section{SUMÁRIO:}

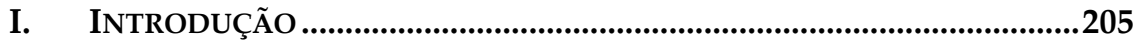

II. INTRODUZINDDO A TEORIA DA COMPLEXIDADE ...............................209

1. A Visão Convencional .............................................................210

2. A Tese da Complexidade.........................................................212

3. A Literatura das Regras de Votação.......................................216

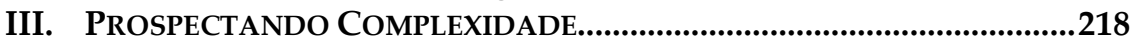

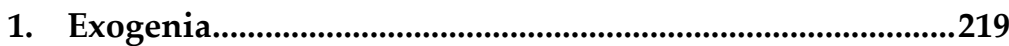

1.1. Argumentos Exógenos para o Originalismo....................219

1.2. Argumentos Exógenos para o Não-Originalismo.............223

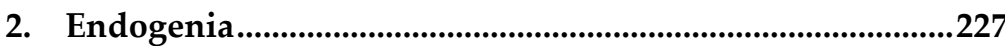

2.1. Argumentos Endógenos para o Não-Originalismo..........228

2.2. Argumentos Endógenos para o Originalismo.................231

2.3. A Constituição de Duas-Velocidades de Aziz Huq ..........234

3. Resumindo ........................................................................235

IV. IMPLICAÇÕES DA COMPLEXIDADE .................................................2236

1. Escolha Interpretiva ................................................................236

1.1. Dificuldade de Emendar e Argumentos Exógenos ...........237

1.2. Dificuldade de Emendar e Argumentos Endógenos.........238

1.3. Argumentos Exógenos vs. Endógenos ...........................239

2. Interpretação Judicial vs. Interpretação Constitucional ...240

2.1. O Estado-da-Arte........................................................240

2.2. Divergência ou Convergência? .........................................241

2.3. A Tese da Complexidade Aplicada .................................244

3. Interpretação Constitucional do Estadual vs. Federal........247

V. AINDA MAIS COMPLEXIDADE ............................................................250

1. Premissas Institucionais ............................................................251

2. Competência Institucional Comparada ..................................253

3. O Impacto da Escolha Interpretativa na Dificuldade

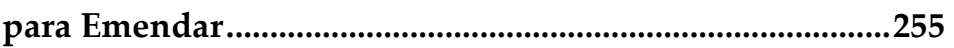

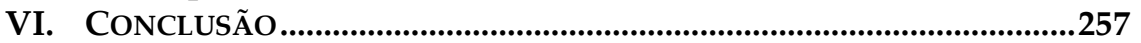

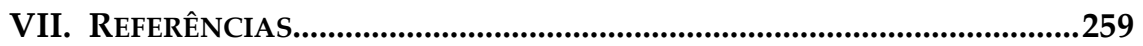




\section{INTRODUCTION}

Imagine a hypothetical U.S. Constitution, identical to the actual Constitution but for one alteration: In place of a two-thirds majority in both houses of Congress and ratification by three-fourths of state legislatures, Article $\mathrm{V}$ requires only a petition to propose and a national popular initiative to ratify constitutional amendments. Would such a lax amendment procedure substantially weaken the arguments against originalism in constitutional interpretation? Many constitutional scholars seem to believe that it would. Certainly, many scholars believe that the extreme difficulty of amending the U.S. Constitution is an important reason for rejecting originalism as impractical and undesirable. The Constitution is almost impossible to fix through the formal amendment process. Ergo, it should be fixed, or kept up to date, in the only way possible-through flexible interpretation. Or so the argument generally goes.

So pervasive is this view that it is often simply assumed or taken for granted. As a result, when it is mentioned in the literature at all, it is more often alluded to than explained or defended. Peter Smith's statement is representative:

Non-originalism has long been animated by the concern that the Constitution, which can be amended only through a difficult super-majoritarian procedure, risks losing legitimacy today if it cannot be read to embody modern, rather than anachronistic, values. ${ }^{1}$

In a nutshell, the difficulty of Article $\mathrm{V}$ amendment weakens the case for originalism. Call this the "conventional view."

This view may ultimately be right, but its familiarity and intuitive appeal obscure something important. The conventional view is not a freestanding argument against originalism. It rests on contestable normative and empirical premises that require defense. More specifically, it rests on a particular family of contested arguments for nonoriginalism. If those arguments are correct, so is the conventional view. But if other arguments for nonoriginalism - or any of the various arguments for originalism - are correct, the conventional view is wrong. In other words, the relation between difficulty of amendment and interpretive choice is complex. The stringency of Article $\mathrm{V}$ might weaken the case for originalism, as the conventional view contends, or it might strengthen that case. Or Article $\mathrm{V}$ might have no impact on that case one way or another. The answer depends on the goals motivating

${ }^{1}$ Peter J. Smith, How Different Are Originalism and Non-Originalism? 62 HASTINGS L.J. 707, 714 (2011). 
the interpretive enterprise and the empirical relation between those goals and difficulty of amendment.

Recognizing this complexity highlights and clarifies the role that difficulty of amendment plays across a range of significant interpretive debates, including those surrounding writtenness, John Hart Ely's representation-reinforcement theory, interpretive pluralism, and originalism as a theory of positive law. It also has important implications for the under-studied relations between statutory and constitutional interpretation and federal and state constitutional interpretation. Call this the "complexity thesis." We shall spend the remainder of this Article defending it.

The core claim of the complexity thesis is straightforward. The relation between difficulty of amendment and interpretive choice turns on contestable normative and empirical premises. On some of these premises, the conventional view is correct. On others, that view has it exactly backward. On still others, difficulty of amendment has no effect at all on interpretive choice.

A few examples will be helpful. Consider the view that contemporary public opinion is an important factor in choosing an interpretive approach. Starting from this premise, an increase in difficulty of amendment might make originalism less attractive by systematically decreasing the alignment between public opinion and original meaning. The more difficult the amendment procedure, the less likely that a public opposed to the Constitution's original meaning will be able to change it through formal channels. An increase in the difficulty of amendment might also systematically decrease the likelihood that the Constitution's original meaning will be well adapted to contemporary circumstances. The more difficult the amendment procedure, the less likely that forces seeking to adapt the Constitution to meet new challenges will be able to do so.

If these empirical premises are correct, and if alignment with contemporary public opinion or adaptation to contemporary circumstances is an important criterion for interpretive choice, very difficult amendment procedures should make originalism less attractive, all else equal. Conversely, less stringent amendment procedures should make it more attractive.

Adherents of the conventional view probably have something like this in mind when they assume or assert that the difficulty of Article $\mathrm{V}$ amendment weakens the case for originalism. They are rarely explicit about it, however. More important, none of the empirical or normative premises on which this logic depends is inevitable. As an empirical 
matter, difficulty of amendment may have no systematic effect on the popularity or pragmatic desirability of original meanings. As a normative matter, contemporary public opinion and adaptation to contemporary circumstances may simply be the wrong criteria for choosing an interpretive approach.

Perhaps, for example, originalism is inherent in the nature of interpretation or written constitutionalism or binding law. If that is the case, it makes no difference whether the Constitution is easy or difficult to amend. The right interpretive answer will always be the originalist answer. Or perhaps the goal of legal and constitutional interpretation ought to be social justice or some other objectively correct understanding of political morality. Originalism may or may not be an attractive means to that end. But its attractiveness will depend entirely on the substantive defensibility of original meaning. Difficulty of amendment, on these views, has no effect on the persuasiveness of originalism or nonoriginalism.

In sum, the relation between difficulty of amendment and interpretive choice turns on contestable normative and empirical premises whose importance the conventional view, by its very familiarity, has obscured. Not coincidentally, many of these normative and empirical premises are at the heart of broader theoretical debates over constitutional interpretation. Conventional wisdom has long assumed that we can intelligently discuss difficulty of amendment and interpretive choice without careful reference to these broader debates. The complexity thesis shows that we cannot.

This insight has several important implications:

First, it clarifies that the conventional view is only as strong as its underlying empirical and normative premises. If those premises are mistaken or irrelevant, as many influential arguments for and against originalism implicitly hold them to be, the extreme difficulty of amending the U.S. Constitution does nothing to weaken the case for originalism. Nonoriginalists who reject those premises cannot coherently invoke the conventional view as either a sword or a shield. Conversely, originalists who reject those premises need not feel embarrassed or defensive about the difficulty of Article $\mathrm{V}$ amendment. In fact, on some normative and empirical premises, the extreme difficulty of amendment actually strengthens the case for originalism.

Second, the complexity thesis illuminates - and complicates - the oftdiscussed divergence between constitutional and statutory interpretation. One obvious difference between statutes and constitutions is that the latter are typically more difficult to amend. On some empirical and normative premises, this difference helps to explain and justify the broader appeal originalism seems to enjoy in statutory 
interpretation. On others, it does not. This complexity undercuts facile arguments for convergence between the two types of interpretation. It also suggests that their divergence in practice merits greater theoretical attention than it has received to date.

Third, the complexity thesis illuminates the under-discussed contrast between constitutional interpretation at the state and federal levels. With several notable exceptions, the conventional wisdom remains that interpretive theories and arguments developed in connection with the U.S. Constitution can be extended straightforwardly to the interpretation of state constitutions. But there are many important differences between the two. Of greatest interest for our purposes, most state constitutions are much easier to amend than is the U.S. Constitution.

This is common knowledge, of course. But the complexity thesis highlights its significance for interpretive choice. On some empirical assumptions and normative premises, this difference in difficulty of amendment provides reason to expect-or hope-that state constitutional interpretation will be more (or less) originalist than interpretation of the U.S. Constitution. On others, this difference should produce no divergence in interpretive choice. As with statutory interpretation, the complexity thesis undercuts facile arguments, for both convergence and divergence.

Our argument unfolds as follows. Part II lays out the conventional view and develops the complexity thesis as an alternative. Part III applies the complexity thesis to several different arguments for and against originalism, demonstrating that difficulty of amendment affects the persuasiveness of some but not others. Part IV considers the implications of the complexity thesis for interpretive choice in constitutional law; the relationship between statutory and constitutional interpretation; and the relationship between constitutional interpretation at the federal and state levels. Part V introduces and addresses three additional complicating factors: our institutional assumptions; comparative institutional competence; and the impact of interpretive choice on difficulty of amendment.

Throughout, we take no position either on the debate between originalism and nonoriginalism or on any of the intramural controversies among the adherents of these views. Our ambition is simply to lay out the analytic structure of the relationship between difficulty of amendment and interpretive choice. For ease of exposition, we start by assuming a judicial interpreter and a political amendment process. In Part V, we relax this simplifying assumption and examine 
the interplay between difficulty of amendment, interpretive choice, and comparative institutional competence. Ultimately, the complexity thesis holds regardless of the institutional position of the interpreter or the nature of the amendment process.

Finally, we develop our argument principally by reference to U.S. constitutional interpretation, for two reasons: It is what we know best, and the extreme difficulty of amending the U.S. Constitution has given rise to an especially rich literature on these questions. The questions themselves, however, are general, and nothing about the complexity thesis is limited to the American context.

\section{INTRODUCING THE COMPLEXITY THESIS}

The extreme difficulty of amending the U.S. Constitution is a commonplace of the constitutional law literature. Early empirical research suggested and more recent work confirms that few, if any, national constitutions are more resistant to change. ${ }^{2}$ This rigidity has been much criticized by American constitutional theorists. ${ }^{3}$ One has gone so far as to identify Article $\mathrm{V}$ as the single worst provision of the original constitutional text. ${ }^{4}$ Yet for all this descriptive and critical attention, there has been little sustained discussion of the relationship between difficulty of amendment and interpretive choice. Instead, most theorists have simply assumed that a difficult amendment process makes originalism less attractive and nonoriginalism more so. We call this "the conventional view."

This Part begins by describing that view and canvassing the sparse

2 See Donald S. Lutz, Toward a Theory of Constitutional Amendment, in RESPONDING TO IMPERFECTION: THE THEORY AND PRACTICE OF CONSTITUTIONAL AMENDMENT 237 (Sanford Levinson, ed., 1995); ZACHARY ElKINS, TOM GINSBURG \& JAMES MELTON, THE ENDURANCE OF NATIONAL CONSTITUTIONS (2009). This literature also suggests that difficulty of amendment is not merely a question of formal procedures. Political culture, party structure, and constitutional length also play an important roleperhaps a more important one. When we talk about "difficulty of amendment," we mean it in this broader sense.

${ }^{3}$ See, e.g., Bruce Ackerman, The Living Constitution, 120 HARV. L. REV. 1737 (2007);

Robert G. Dixon, Jr., Article V: The Comatose Article of Our Living Constitution?, 66 MicH. L. REV. 931 (1968); Philip A. Hamburger, The Constitution's Accommodation of Social Change, 88 MicH. L. REV. 239 (1989); David A. Strauss, The Irrelevance of Constitutional Amendments, 114 HARV. L. REV. 1457 (2001).

${ }^{4}$ Stephen M. Griffin, The Nominee is ... Article V, 12 CONST. COMMENT. 171 (1995). 
discussion of it in the existing literature. We then lay out our own preferred alternative, which we call "the complexity thesis." As the name implies, this thesis holds that the relationship between difficulty of amendment and interpretive choice is complex. On some empirical assumptions and normative premises, increasing the difficulty of amendment makes originalism less attractive. On others, it does the opposite. On still others, difficulty of amendment increases the stakes of interpretive choice but has no implications at all for the attractiveness of originalism or nonoriginalism.

The Part concludes with a discussion of the normative literature on voting rules and constitutional amendment procedures. This literature is relevant to our project but does not subsume it. The relationship between difficulty of amendment and interpretive choice is not simply a proxy for the debate over optimal constitutional amendment procedures.

\section{The Conventional View}

The conventional view is simply stated: The more difficult it is to amend a constitution, the less attractive an originalist interpretive approach becomes. It is relatively easy to find constitutional theorists asserting or assuming some variation on this view. The passage from Peter Smith we quoted earlier is a good example. ${ }^{5}$ Others abound. ${ }^{6}$ It is much harder, however, to find a rigorous defense of this view. In fact,

${ }^{5}$ See Smith, supra note 1.

${ }^{6}$ See, e.g., Lawrence B. Solum, Communicative Content and Legal Content, 89 NOTRE DAME L. REV. 479, 513-14 (2013) ("[L]iving constitutionalists frequently invoke the difficulty of constitutional amendment, the age of the Constitution, and associated problems of the dead hand when they argue that the Supreme Court should have authority to adopt constitutional constructions that contradict the constitutional text."); RICHARD POSNER, REFLECTIONS ON JUDGING 194 (2013) ("Because of the difficulty of amending the Constitution, it has from the beginning been loosely construed so that it would not become a straight-jacket."); Terrance Sandalow, Constitutional Interpretation, $79 \mathrm{MiCH}$. L. REV. 1033, 1046 (1981) ("Reference to the 'important objects' of the framers rather than their specific intentions is, no doubt, a necessity if the evolving needs of the nation are to be served. The amendment process established by article V simply will not sustain the entire burden of adaptation that must be borne if the Constitution is to remain a vital instrument of government.")

1 JOURNAL OF INSTITUTIONAL STUDIES 1 (2015) 
despite extensive searching, we have not been able to find a single one. We do not believe that this paucity of explicit discussion reflects a lack of support for the conventional view. To the contrary, we believe it reflects a widespread assumption that the truth of the view is too obvious to require a defense.

We base this belief in part on numerous conversations with colleagues over the course of many years but also on two inferences from the literature. First, originalists persistently view the difficulty of Article $\mathrm{V}$ amendment as an embarrassment to be explained away. ${ }^{7}$ That this would be so suggests a view on the part of their nonoriginalists interlocutors - still a sizeable majority among constitutional theoriststhat Article V's rigidity makes originalism less attractive.

Second, and relatedly, the conventional view is implicit in a standard series of thrusts and parries over the dead-hand objection to originalism:

1. Thrust: The original meaning of the constitutional text is the only one the American people ratified; ergo, popular sovereignty demands that subsequent interpreters follow that meaning.

2. Parry: The American people who ratified the Constitution are all dead and are also very different from contemporary Americans.

3. Thrust: If contemporary Americans want to change the Constitution's original meaning, they can always amend it.

4. Parry: Article V makes constitutional amendment practically impossible or, at the very least, permits a tiny minority of the population to block desirable change. ${ }^{8}$

There are two important points for our purposes. The first is the

7 See, e.g., A Simple (and Serious) Puzzle for Originalists, ERIC POSNER (Jan. 21, 2014, 2:00 $\mathrm{AM})$, http://ericposner.com/a-simple-and-serious-puzzle-for-originalists/; Debra Cassens Weiss, "How Scalia and Ginsburg Would Amend the Constitution," ABA Journal, April 21, 2014, available at

http://www.abajournal.com/news/article/how scalia and ginsburg would amend th e constitution/ ("Scalia said he would change the amendments provision to make amendments easier.").

8 See, e.g., CASs R. Sunstein, Legal Reasoning AND POlitiCAl Conflict 175 (1996) [hereinafter SUNSTEIN, REASONING]; CASS R. SUNSTEIN, THE PARTIAL CONSTITUTION 100 (1993) [hereinafter SUNSTEIN, PARTIAL]; Andrew Coan, Talking Originalism, 2009 BYU L. REV. 847 [hereinafter COAN, Talking]; Richard A. Primus, When Should Original Meanings Matter?, 107 Mich. L. REV. 165 (2008). 
utter familiarity of this pas de deux. Anyone who has taken a first-year Constitutional Law course will recognize it. The second is the assumption underlying step 4 that a difficult amendment process makes originalism less attractive than it otherwise might be. That is the conventional view in a nutshell.

What motivates this view? In the context of the dead-hand problem, it is the relationship between difficulty of amendment and popular sovereignty. The more stringent the amendment procedure, the greater the risk that political minorities will block popular changes to the Constitution's original meaning. We will have more to say about this line of argument in Part III. More generally, the conventional view rests on a superficially plausible but largely unexamined intuition: Where constitutional problems are difficult to correct by amendment, interpreters should necessarily possess greater power to correct them through flexible interpretation. The more stringent the amendment procedure, the greater the justification for interpretive flexibility.

The appeal of this intuition is straightforward. The purpose of the amendment process is to fix constitutional problems. As the stringency of amendment procedures increases, the need for substitute mechanisms for fixing problems with the Constitution's original meaning would seem also to increase. One obvious substitute is the process of interpretation, which exercised creatively holds the potential to radically reshape the Constitution's practical operation, within capacious outer limits. The more stringent the amendment procedure, the greater the apparent need for this sort of alternative mechanism for addressing constitutional problems.

\section{The Complexity Thesis}

This line of argument may ultimately be correct, but the relation between interpretive choice and difficulty of amendment is significantly more complex than it allows. On some normative and empirical premises, increasing the difficulty of amendment makes originalism less attractive, as the conventional view contends. On others, however, increasing the difficulty of amendment makes originalism more attractive. On still others, it increases the stakes of interpretive choice but has no implications at all for the attractiveness of originalism or nonoriginalism. This is the complexity thesis in a nutshell.

As an illustration, consider the family of interpretive arguments grounded in popular sovereignty and consequentialism. These 
normative considerations are frequently invoked as important-even dispositive-metrics for determining the optimal interpretive approach. Originalists sometimes defend originalism as necessary to preserve popular sovereignty, ${ }^{9}$ and nonoriginalists frequently reject originalism as incompatible with the sovereignty of present-day citizens. ${ }^{10}$ Similarly, some originalists defend originalism on the basis of its desirable consequences, while many nonoriginalists reject originalism based on what they perceive to be its intolerable consequences. ${ }^{11}$

Difficulty of amendment might plausibly be thought to have significant bearing on the soundness of these arguments. At relatively low levels of difficulty, originalists might have a plausible argument that original meanings are consistent with popular sovereignty. Otherwise, those meanings would be overturned by amendment. ${ }^{12}$ As amendment becomes more difficult, however, this argument becomes harder to sustain. In the limiting case, where a constitution is impossible or virtually impossible to amend, it seems extremely doubtful that the original meaning of its provisions will be consistent with the values, views, and preferences of present-day citizens. If this is true and the sovereignty of contemporary democratic majorities is normatively dispositive, increasing the difficulty of amendment weakens the case for originalism. ${ }^{13}$

9 See, e.g., RAOUl BERGER, GOVERNMENT BY JUdiCIARY: THE TRANSFORMATION OF THE FOURTEENTH AMENDMENT (1977); ROBERT BORK, THE TEMPTING OF AMERICA 143 (1990); KeITH E. WhitTINGTON, CONSTITUTIONAL INTERPRETATION: TEXTUAL MEANING, ORIGINAL INTENT, AND JUDiCIAL REVIEW 110-59 (1999); Richard S. Kay, Adherence to the Original Intentions in Constitutional Adjudication: Three Objections and Responses, $82 \mathrm{NW}$. U. L. REV. 226, 234 (1988).

10 See JOHN HART Ely, DEMOCRACY AND Distrust: A THEORY OF JUdicial REVIEW 11 (1980); CASS R. SUNSTEIN, RADICALS IN ROBES: WHY RADICAL RigHT Wing JUdGES ARE WRONG FOR AMERICA 74-76 (2005); SUNSTEIN, REASONING, supra note 8; SUNSTEIN, PARTIAL, supra note 8; Paul Brest, The Misconceived Quest for Original Understanding, 60 B.U. L. REV. 204, 204-38 (1980); Coan, Talking, supra note 8, at 852; Michael Klarman, Antifidelity, 70 S. CAL. L. REV. 381 (1997); Primus, supra note 8, at 192-93.

${ }_{11}$ See Coan, Talking, supra note 8, at 865; Cass R. Sunstein, If People Would be Outraged by Their Rulings, Should Judges Care?, 60 STAN. L. Rev. 155, 167 (2007); Cass R. Sunstein, Of Snakes and Butterflies: A Reply, 106 COLUM. L. REV. 2234, 2236 (2006).

${ }^{12}$ Note that this argument assumes an originalist judiciary. If judicial interpretations are more nonoriginalist than originalist, the implied consent through acquiescence argument favors nonoriginalism. See Primus, supra note 8, at 189-90.

13 This is the essential logic of the dead hand objection and, we suspect, the principal intuition behind the conventional view. 
The interplay between consequentialism and difficulty of amendment is similar. At relatively low levels of difficulty, originalists might have a plausible argument that original meanings have proved reasonably workable over time and therefore embody a kind of Burkean collective wisdom. ${ }^{14}$ Those meanings that were found seriously unworkable would simply be overturned by amendment. But again, as amendment becomes more difficult, this argument becomes harder to sustain. The more difficult the amendment process, the more likely that unworkable original meanings will remain unchanged despite their unworkability. If this is true, increasing the difficulty of amendment decreases the strength of the consequentialist case for originalism.

In each of these examples, the relationship between originalism and difficulty of amendment is endogenous. The attractiveness of the former changes with, and because of, the latter. So far, so good for the conventional view. Popular sovereignty and consequentialism do not, however, exhaust the potential normative grounds for originalism. Perhaps originalism is best justified on the ground that it is the only approach that qualifies as constitutional interpretation. Or perhaps it is the only approach consistent with written constitutionalism. Neither of these justifications for originalism is sensitive to difficulty of amendment. If either of them is correct, originalism will be the best approach under any amendment procedure. In these examples, the relationship between originalism and difficulty of amendment is exogenous.

Even if popular sovereignty or consequentialism is the best justification for originalism, the empirical relation between these normative principles and difficulty of amendment is far from straightforward. Perhaps increasing difficulty of amendment increases the likelihood that constitutional provisions will be old, which in turn increases public veneration for their original meaning. If this is true, difficulty of amendment and interpretive choice might be endogenous but in the direction opposite to that assumed by the conventional view. That is, increasing the difficulty of constitutional amendment might make originalism more attractive, not less.

Another possibility is that public opinion follows a cyclical path or fluctuates randomly over time, so that the original meaning of an old

14 See David A. Strauss, Common Law Constitutional Interpretation, 63 U. CHI. L. REV. 877 (1996); David A. Strauss, Common Law, Common Ground, and Jefferson's Principle, 112 YALE L.J. 1717 (2003); Cass R. Sunstein, Burkean Minimalism, 105 MicH. L. ReV. 353 (2006). 
constitution is no more or less likely to align with contemporary public opinion than the original meaning of a newer-because more frequently amended-constitution. If this is the case, difficulty of amendment will have no impact on the strength of the case for originalism. In other words, its relation to interpretive choice will be exogenous.

The same point holds for consequentialism. Increasing the difficulty of amendment might promote deliberation and public spiritedness in the drafting and ratification of new constitutional provisions, leading the original meaning of those provisions to produce better constitutional consequences. ${ }^{15}$ Or the relationship between difficulty of amendment and good consequences might be random, such that the former has no impact at all on the latter. The important point is not that either of these empirical propositions is true. It is that they are within the realm of plausibility and crucial to determining the nature of the interplay between interpretive choice and difficulty of amendment.

The upshot is that the relationship between interpretive choice and difficulty of amendment depends on the normative and empirical assumptions underlying competing approaches to interpretive choice. Some arguments for and against originalism are endogenous-that is, they are sensitive, in one direction or the other, to the difficulty of constitutional amendment. This sensitivity has both normative and empirical predicates. Other arguments for and against originalism are exogenous - they are unaffected by difficulty of amendment. In other words, the relationship between difficulty of amendment and interpretive choice is complex. Broad generalizations like the conventional view mask this complexity and promote confusion.

In Part III, we cash out the complexity thesis, surveying a range of common arguments for and against originalism and classifying them as endogenous or exogenous. In Part IV, we explain why this distinction matters. The short version is that the conventional view cannot be persuasively invoked to support exogenous arguments for nonoriginalism or to oppose exogenous arguments for originalism - at least not without engaging their underlying normative premises. This insight has important implications not only for constitutional theory itself, but also for the under-studied relations between statutory and constitutional interpretation and federal and state constitutional interpretation.

${ }^{15}$ See, e.g., JOHN O. MCGINNIS \& MichaEl B. RAPPAPORT, ORIGINALISM AND THE GOOD CONSTITUTION (2013); John O. McGinnis \& Michael B. Rappaport, Our Supermajoritarian Constitution, 80 TEX. L. REV. 703 (2002) [hereinafter McGinnis \& Rappaport, Supermajoritarian]. 


\section{The Voting-Rules Literature}

Before moving on, we feel compelled to say a few words about the substantial and sophisticated literature on voting rules. ${ }^{16}$ As it pertains to constitutional amendment, this literature supplies a standard menu of arguments for and against robust supermajority procedures. To oversimplify greatly, supermajoritarian amendment procedures are classically justified as necessary to prevent tyranny of the majority, to ensure political stability, to promote social cohesion and minority buyin, and to induce public-spirited, long-term decision-making. ${ }^{17}$ Majoritarian procedures, by contrast, are traditionally defended on the grounds of equal respect, utilitarianism, the wisdom of many minds, and May's Theorem. ${ }^{18}$

Our focus, of course, is not the optimal design of constitutional amendment procedures but the relationship between those procedures and interpretive choice. Taking an amendment procedure as given, what are its implications for constitutional interpretation, as compared to more or less stringent alternatives? Superficially, this question appears entirely independent of the question addressed by the votingrules literature. But again, the appearance is deceiving. Within capacious outer limits, flexible constitutional interpretation can serve as a near-perfect substitute for constitutional amendment. ${ }^{19}$ The result is to

${ }^{16}$ For recent contributions, see Vijay Krishna \& John Morgan, Majority Rule and Utilitarian Welfare (2012), AM. ECON. J.: MiCROECONOMICS (forthcoming), available at

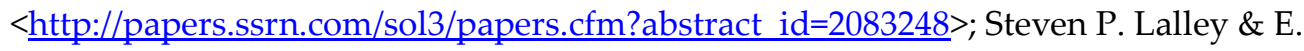
Glen Weyl, Quadratic Voting (2015), available at $<$ http://papers.ssrn.com/sol3/papers.cfm?abstract id=2003531>; Eric A. Posner \& E. Glen Weyl, Voting Squared: Quadratic Voting in Democratic Politics, 68 VAND. L. ReV. (forthcoming 2015), available at $<$ http://papers.ssrn.com/sol3/papers.cfm?abstract id=2343956 $>$.

17 See Melissa SchWARTZBERG, COUNTING THE MANY: THE Origins AND LiMits OF SUPERMAJORITY RULE 4 (2013).

${ }^{18} \mathrm{Id}$. at 8 . The latter establishes that majority rule is the only decision procedure that satisfies the formal criteria of decisiveness, anonymity, neutrality, and positive responsiveness. $I d$. at 121 .

${ }^{19}$ The U.S. Supreme Court's 1937 "switch in time" - radically expanding federal power through judicial interpretation - and post-ERA sex discrimination decisions are the classic examples. 
make formally stringent amendment procedures far less stringent in practice.

Interpretive choice and constitutional amendment are thus interdependent. This interdependence is reflected in the common originalist complaint that nonoriginalist approaches subvert the carefully calibrated amendment procedures of Article V. ${ }^{20}$ It is also reflected in the conventional view that the stringency of Article $\mathrm{V}$ makes originalism indefensible and necessitates interpretive updating. These arguments illustrate a familiar point from the literature: many debates over interpretive choice are really proxy debates over Article V. ${ }^{21}$ To this extent, all the arguments from the voting-rules literature have direct application to the question of interpretive choice.

To almost precisely the same extent, the arguments from the votingrules literature have direct application to the relationship between difficulty of amendment and interpretive choice. The reason is simple. Arguments against (or for) originalism that track difficulty of amendment are based almost entirely on its promise to render supermajoritarian amendment rules effective. In this sense, these arguments are-perhaps unbeknownst to their proponents-really proxies for arguments against (or for) stringent amendment procedures. They are thus subject to all the defenses and objections to supermajoritarian amendment procedures elaborated in the voting-rules literature.

As we have emphasized, however, not all interpretive arguments have this character. Indeed, this is our central point. In contrast to the arguments we have identified as endogenous, those we have identified as exogenous are unaffected by the difficulty of constitutional amendment. Neither the first-order debate over these arguments nor their relationship to difficulty of amendment is illuminated-much less resolved - by arguments from the voting-rules literature.

In sum, the voting-rules literature has substantial implications for the persuasiveness of endogenous interpretive arguments. It may also have important implications for the relative persuasiveness of endogenous and exogenous arguments. Our focus, however, is on the analytic structure of the relationship between difficulty of amendment and interpretive choice. We take no position on the validity of any individual argument or class of arguments. We will therefore have no

\footnotetext{
${ }^{20}$ McGinnis \& Rappaport, Supermajoritarian, supra note 15; Lee J. Strang, Originalism and the "Challenge of Change": Abduced-Principle Originalism and Other Mechanisms by Which Originalism Sufficiently Accommodates Changed Social Conditions, 60 HASTINGS L.J. 927 (2009).

${ }^{21}$ See Coan, Talking, supra note 8 at 855.
} 
more to say about the voting-rules literature.

\section{III.CASHING OUT COMPLEXITY}

The relationship between difficulty of amendment and interpretive choice is complex. That does not mean that it is muddled, hazy, or ambiguous. In fact, the relationship can be mapped fairly schematically. Arguments about interpretive choice, both for and against originalism, rest on normative and empirical premises. On some of those premises, difficulty of amendment affects the attractiveness of different interpretive approaches. On other premises, difficulty of amendment has no effect on interpretive choice. We call arguments in the former category endogenous and arguments in the latter exogenous. Each category comprises influential arguments for both originalism and nonoriginalism

In this Part, we offer a systematic map of those arguments. This map is meant to be illustrative rather than comprehensive. We certainly do not and could not hope to address every important interpretive argument here. Nor could we do full justice to all the nuances of the arguments we do discuss. ${ }^{22}$ Our goal is merely to summarize their broad outlines and to capture the core premises common to most of their adherents. Finally, little of importance turns on our categorization of any given individual argument. The crucial point is that leading arguments for and against originalism fall into both categories.

${ }^{22}$ To take just one example, changed-circumstances and democratic-legitimacy arguments for nonoriginalism apply with considerably less force to versions of "New Originalism" that permit substantial evolution in constitutional applications or constructions over time. See, e.g., Steven G. Calabresi \& Hannah M. Begley, Originalism and Same Sex Marriage (October 13, 2014). Northwestern Public Law Research Paper No. 14-51. Available at SSRN: http://ssrn.com/abstract=2509443 or http://dx.doi.org/10.2139/ssrn.2509443 (arguing that same-sex marriage bans violate the original meaning of the $14^{\text {th }}$ amendment); Steven G. Calabresi \& Julia Rickert, Originalism and Sex Discrimination, 90 TEX. L. REV. 1 (2011) (making a similar argument about government sex discrimination). Indeed, it is increasingly difficult to distinguish originalism of this sort from living constitutionalism. See, e.g., JACK BALKIN, LIVING ORIGINALISM (2011). This complicates the application of traditional normative arguments - both pro and con - to this family of originalist views, but it does not affect the complexity thesis. 


\section{Exogeneity}

Exogenous interpretive arguments, like any other class of interpretive argument, may or may not be persuasive. Their persuasiveness, however, is not affected one way or the other by difficulty of amendment. This is their central defining characteristic.

\subsection{Exogenous Arguments for Originalism}

Two of the most important arguments to emerge from the recent originalist literature rest on the nature of interpretation and the "writtenness" of the U.S. Constitution. Both are exogenous as we use that term. Both are also, in some sense, arguments from necessity. This common characteristic helps to explain their exogeneity. As arguments from necessity, they are not sensitive to variations in circumstance, including variations in the difficulty of constitutional amendment. A third originalist argument-that original meaning is binding positive law - is not an argument from necessity but depends on social facts that bear no obvious relation to difficulty of amendment.

\section{a. The Nature of Interpretation}

Arguments from the nature of interpretation have a venerable pedigree, but prominent theorists like Keith Whittington, Stanley Fish, Larry Alexander, and others have given them new currency. ${ }^{23}$ Proponents of this family of arguments for originalism differ on some particulars but agree on a relatively straightforward essential core. Interpretation is a distinctive activity, with a knowable nature. It encompasses the search for a text's original public meaning (or the drafter's original intent, as some would have it) but not other text-based activities such as the search for a text's contemporary meaning or the meaning most consistent with political morality or evolving standards of decency. No one would interpret a recipe or the Articles of

${ }^{23}$ WhitTINGTON, supra note 9; Stanley Fish, Interpretation is All There Is: A Critical Analysis of Aharon Barak's Purposive Interpretation in Law, 29 CARDOZO L. REV. 1109, 1112 (2008); Larry Alexander, Simple-Minded Originalism (San Diego Legal Studies Paper No. 08-067, 2008), available at $<$ http://papers.ssrn.com/sol3/papers.cfm?abstract id=1235722>. 
Confederation in these ways, and the Constitution is no different. ${ }^{24}$ As Stanley Fish puts it, originalism is "not an approach to interpretationone possible method in competition with other methods-it is interpretation." 25 It follows, by inexorable deductive logic, that judges and others purporting to interpret the Constitution must be originalists. Anyone who departs from originalism is simply not engaged in constitutional interpretation.

This argument may or may not be persuasive. One of us is on record arguing that it is not. ${ }^{26}$ But either way, it is completely insensitive to the difficulty of amendment. Assuming that interpretation has a knowable nature that encompasses only originalism, difficulty of amendment changes nothing. Under a stringent amendment procedure or a lax one or anywhere in between, interpretation simply is the search for the text's original meaning. To repeat, this does not mean the argument succeeds. Either of its key assumptions might be faulty, but their soundness is not affected one way or the other by difficulty of amendment. Of particular relevance to the conventional view, their soundness is not undermined by the extreme difficulty of amending the U.S. Constitution. For all of these reasons, the argument from interpretation is a textbook example of an exogenous argument.

\section{b. Written Constitutionalism}

Another important exogenous argument for originalism is the argument from writtenness advanced by Randy Barnett, ${ }^{27}$ Jack Balkin, ${ }^{28}$ and others. ${ }^{29}$ This argument may be the most novel normative contribution of the New Originalism. It is certainly one of the most important distinctions the New Originalists drew between themselves

\footnotetext{
${ }^{24}$ Gary Lawson, On Reading Recipes ... and Constitutions, 85 GEO. L.J. 1823, 1828 (1997).

${ }^{25}$ Fish, supra note 23.

${ }^{26}$ Andrew Coan, Irrelevance of Writtenness in Constitutional Interpretation, 158 U. PENN.

L. REv. 1025, 1071-83 (2010) [hereinafter Coan, Irrelevance]; Coan, Talking, supra note 8 at 849-52; see also Cass R. Sunstein, There is Nothing that Interpretation Just Is (2014), available at $<$ http://papers.ssrn.com/sol3/papers.cfm?abstract id $=2489088>$.

${ }^{27}$ See Randy E. Barnett, An Originalism for Nonoriginalists, 45 LOY. L. ReV. 611 (1999).

${ }^{28}$ See Jack M. Balkin, Framework Originalism and the Living Constitution, 103 NW. U. L. REV. 549 (2009).

${ }^{29}$ See, e.g., WHITTINGTON, supra note 9.
} 
and their predecessors.

The argument from writtenness takes a variety of forms, some of them parasitic on other, endogenous justifications for originalism, such as popular sovereignty and the rule of law. ${ }^{30}$ In its strongest version, however, the argument is offered as a freestanding reason why judges should embrace an originalist approach to constitutional interpretation. The idea is that writing, by its very nature, fixes the meaning of a text at the moment it is written. Otherwise, written words are no more than meaningless marks on a page, subject to the whim and caprice of every individual reader who chances upon them. Ergo, the constitutional text must be interpreted according to its original meaning. That is simply what it means to be committed to a written constitution. ${ }^{31}$

The persuasiveness of this argument may be doubted. ${ }^{32}$ But like the argument from the nature of interpretation, it does not depend on the difficulty of constitutional amendment. Restated to emphasize its two key premises, the argument from writtenness maintains (1) that originalism can successfully explain commitment to written constitutional text and (2) that no other approach can. Premise (1) turns on the power of writing to fix linguistic meaning at a particular point in time. Premise (2) turns on this being writing's only conceivable function. At bottom, both are conceptual claims about the nature and functions of written communication. Since the difficulty of constitutional amendment has no effect on the nature and functions of written communication generally, it does not affect the soundness of the argument from writtenness. In other words, that argument is exogenous as we are using the term.

\section{c. Original Meaning as Positive Law}

A third exogenous argument for originalism maintains that it is the only interpretive approach to treat the Constitution as binding positive law. Some versions of this argument rest on unsatisfying definitional equivalences between the Constitution and its original meaning. ${ }^{33}$ Others appear to rest on an outdated Austinian positivism, under which only the commands of some identifiable sovereign qualify as "law." 34

\footnotetext{
${ }^{30}$ See Parts III, IV infra.

31 This paragraph is adapted from Coan, "Irrelevance," supra note 26, at 1027-28.

${ }^{32}$ See id. at 1047-70 (exploring numerous, nonoriginalist forms of commitment to a written constitution).

33 Coan, Irrelevance, supra note 26, at 1083-84.

${ }^{34} \mathrm{Id}$. at 1084 .
} 
Recently, however, Stephen Sachs has advanced a more sophisticated version of this argument. Leaving aside many nuances, Sachs argues that the original meaning of the U.S. Constitution is (or might be) the exclusive source of American constitutional law as a matter of social fact. On this view, originalism "isn't just about recovering the meaning of ancient texts, a project for philologists and historians. Instead, it's about determining the content of our law, today, in part by recovering Founding-era doctrine." 35 In other words, contemporary Americans might still "take the Founders' law as our own." If they do, Sachs argues, this "is the best reason to be an originalist." 36

As Sachs candidly acknowledges, the main premise of this argument is highly contestable. Many aspects of American constitutional practice are difficult to square with a social convention of treating original meaning as the exclusive source of the Constitution's legal content. ${ }^{37}$ For our purposes, however, the correctness of Sachs's view is immaterial. The crucial point is that the persuasiveness of his claim depends on social facts about the legal culture in which originalism is being advocated. Do participants in that culture understand original meaning in the way that Sachs contends contemporary Americans do? This is an empirical question, not a normative one, which turns on the views and attitudes actually prevailing in a given legal culture. It does not in any

${ }^{35}$ Stephen E. Sachs, Originalism as a Theory of Legal Change (2014), HARV. J.L. \& PUB.

POL'Y (forthcoming), available at

$<$ http://papers.ssrn.com/sol3/papers.cfm?abstract $\mathrm{id}=2498838>$; see also William Baude, Is Originalism Our Law?, COLUM. L. ReV. (forthcoming 2015) (on file with author).

${ }^{36} \mathrm{Id}$. (manuscript at 1 ). As Will Baude explains, this reason depends on a supplementary but widely shared commitment to judicial law-following. See Baude, supra note 35 , at 37 . In principle, this commitment could be strong or weak, defeasible or indefeasible. The same, for that matter, goes for any of the exogenous arguments discussed in this section, which could be broadly described as arguments from "legal correctness." Baude himself endorses a defeasible version, subject to override by "more pressing moral concerns." Id. at 39. More generally, it is clearly possible to embrace the exogenous arguments discussed in this section, while simultaneously believing that the difficulty of the Article $\mathrm{V}$ process is sub-optimal and should be changed. For adherents of such arguments, however, the defects of Article Vwhatever they may be-do not affect the proper approach to interpretive choice. ${ }^{37}$ See Coan, Irrelevance, supra note 26, at 1085 (dismissing this view as "plainly false"). Sachs and Baude have convinced us that the issue is more complicated than Coan previously allowed. 
obvious way turn on the difficulty of constitutional amendment..$^{38}$ Thus, Sachs's argument, like arguments from the nature of interpretation and written constitutionalism, is properly categorized as exogenous.

\subsection{Exogenous Arguments for Nonoriginalism}

Exogenous arguments for nonoriginalism seem to be somewhat more rare, perhaps because nonoriginalists tend to be more pragmatic and less formalist than their originalist counterparts. ${ }^{39}$ Nevertheless, three of the most influential arguments for nonoriginalism fit comfortably in this category. Like exogenous arguments for originalism, the persuasiveness of these arguments is wholly unaffected by the difficulty of constitutional amendment.

\section{a. Moral Reading}

Perhaps the best example of an exogenous argument for nonoriginalism is Ronald Dworkin's influential moral-reading approach to constitutional interpretation. ${ }^{40}$ On Dworkin's view, crudely summarized, law is a justice-seeking social practice but one that is constrained to keep a special sort of faith with the past. Constitutional law in particular aspires to a virtue Dworkin calls "integrity," which is defined by a search for principles of political morality that best fit and justify the constitutional text and other authoritative legal materials. The

${ }^{38} \mathrm{~A}$ small caveat is in order. As an empirical matter, difficulty of amendment and a society's inclination to accept original meaning as law might be correlated. Perhaps, for example, societies with difficult amendment procedures are more likely to reject Sachs's "original-law originalism" because, in such societies, original meaning is more likely to seem outdated. On the other hand, perhaps societies with more difficult amendment procedures are more likely to adhere to such originalism because of a veneration for the drafters of the constitutional provisions. We have no idea whether such a systematic correlation exists, but even if it does, it would merely establish a contingent statistical relationship between difficulty of amendment and interpretive choice, not a conceptual or theoretical one. In societies where this relationship did not obtain, changing the difficulty of amendment would have no effect on the persuasiveness of original-law originalism.

${ }^{39}$ This is only a tendency, of course, not an ironclad rule.

${ }^{40}$ Get citations to RONALD DWORKIN, LAW'S EMPIRE (1986) [hereinafter DWORKIN, EMPIRE]; RONALD DWORKIN, TAKING RIGHTS SERIOUSLY (1978). 
best approach to constitutional interpretation is the one that makes the best moral sense of those materials, considered as a whole.

Dworkin himself was severely critical of originalism, on both substantive and feasibility grounds. But as Cass Sunstein has noted, nothing in Dworkin's perfectionist approach to constitutional interpretation permits us to rule out originalism a priori. ${ }^{41}$ Under that approach, the crucial question is whether originalism or some other approach to constitutional interpretation makes the best moral sense of the Constitution. For our purposes, the answer to this question is unimportant. What matters is that the answer turns solely on the moral content of originalist and nonoriginalist interpretations. If nonoriginalism is more attractive than originalism, as Dworkin and his followers generally suppose, it is because nonoriginalism makes better moral sense of the Constitution. Difficulty of amendment is simply immaterial. Thus, Dworkin's moral reading qualifies as an exogenous argument for nonoriginalism.

Two minor caveats are in order. First, if one embraces a teleological view of history, a stringent amendment procedure would make it less likely that originalism would incorporate moral progress. This would obviously reduce its attractiveness relative to nonoriginalism. Second, on some views of political morality, a stringent amendment procedure might itself reduce the moral appeal of the Constitution - for instance, by making it less democratically responsive-in ways that nonoriginalism could at least partially remedy. Again, the result would be to reduce the attractiveness of originalism relative to nonoriginalism.

We do not think either of these caveats justifies classifying the moralreading approach as an endogenous argument. Rather, they illustrate that the complexity thesis applies all the way down. Even arguments that are in the main exogenous can be rendered endogenous by changing their normative and empirical assumptions. As we stated at the outset, this complexity, rather than the categorization of any particular argument, is the central point of this Part.

\section{b. Representation Reinforcement}

Another important exogenous argument for nonoriginalism is John Hart Ely's extraordinarily influential "representation reinforcement"

${ }^{41}$ See Cass R. Sunstein, Second-Order Perfectionism, 75 FORDHAM L. ReV. 2867 (2007)

[hereinafter Sunstein, Perfectionism].

1 JOURNAL OF INSTITUTIONAL STUDIES 1 (2015) 
approach. ${ }^{42}$ Ely's central idea, to oversimplify greatly, was that the Constitution sets up the rules of the political game but neither dictates outcomes nor provides instructions as to its own interpretation. In the face of textual ambiguity, he argued, judges ought to interpret the Constitution (1) to prevent the ins from choking off the channels of political change and (2) to prevent the systematic disadvantaging of discrete and insular minorities. ${ }^{43}$ Put differently, the best interpretive approach is the one that produces the most representative political process.

Like Dworkin, Ely was severely critical of originalism, which he dismissively labeled "clause-bound interpretivism." But also like Dworkin, nothing in Ely's representation-reinforcement approach permits us to rule out originalism a priori. Under that approach, the crucial question is whether originalism or some other method of interpreting the Constitution best reinforces the representative character of American government. Again, for our purposes, the answer to this question is unimportant. What matters is that the answer turns solely on the democratic content of originalist and nonoriginalist interpretations. If nonoriginalism is more attractive than originalism, as Ely and his followers generally suppose, it is because nonoriginalism produces a more representative constitutional order than originalism. Difficulty of amendment is simply immaterial. Thus, Ely's representationreinforcement approach qualifies as an exogenous argument for nonoriginalism.

Again, two minor caveats are in order. First, if one embraces a teleological view of political development, a stringent amendment procedure would make it less likely that the Constitution would incorporate the inexorable march of democratic progress over time. Obviously, this would make originalism less attractive relative to nonoriginalism. Second, on some views of representative democracy, a stringent amendment procedure might itself reduce (or increase) the representativeness of the Constitution-by making majoritarian constitutional change more difficult (or by securing the rights of minorities against majoritarian override). To the extent that nonoriginalism reduces the practical difficulty of constitutional change, it might make the constitutional order more (or less) representative in this respect.

As with Dworkin's moral reading, we do not believe either of these caveats justifies classifying Ely's representation reinforcement approach as endogenous. Rather, they offer one more illustration that the

42 JOHN ELy, DEMOCRACY AND DistruST: A THEORY OF JUdiCIAL REVIEW (1981).

${ }^{43} \mathrm{Id}$. at 103. 
complexity thesis applies all the way down. The very same interpretive argument might be exogenous on some normative and empirical assumptions and endogenous on others.

\section{c. Methodological Pluralism as Positive Law}

A third exogenous argument for nonoriginalism mirrors Stephen Sachs's positivist argument for originalism. This argument, most closely associated with Richard Fallon and Philip Bobbitt, holds that a pluralistic approach -drawing on text, history, structure, etc. - is simply the way competent American practitioners do constitutional interpretation. ${ }^{44}$ Although neither Fallon nor Bobbitt explicitly embraces positivism, ${ }^{45}$ it is relatively easy to recast their arguments in positivist terms. As Richard Primus paraphrases Bobbitt, "[p]erhaps certain forms of argument simply constitute the activity of constitutional reasoning as sanctioned and accepted by the relevant community." 46 This, of course, is just the standard that Hartian legal positivism employs for establishing a norm as positive law. ${ }^{47}$ More precisely, if Fallon and Bobbitt are right, methodological pluralism may constitute the "rule of recognition" that determines the legal validity of first-order constitutional rules. ${ }^{48}$

Whether or not Fallon and Bobbitt would endorse this reformulation, it represents an important and influential argument for nonoriginalism. ${ }^{49}$ As with the other arguments we have canvassed in this Part, the correctness of this argument is immaterial for our purposes. The crucial point is that its persuasiveness depends on social facts about the legal culture in which nonoriginalism is being advocated: Do participants in that culture embrace methodological pluralism in the way that Fallon and Bobbitt contend contemporary Americans do? This is an empirical question, not a normative one, which turns on the views

${ }^{44}$ Richard H. Fallon, A Constructivist Coherence Theory of Constitutional Interpretation, 100 HARV. L. ReV. 1189 (1987); PHILIP BobBITt, CONSTITUTIONAL FATE: TheORY OF THE CONSTITUTION (1984).

${ }^{45}$ Bobbitt is especially difficult to categorize on this issue.

46 Primus, supra note 8 at 183.

${ }^{47}$ See Herbert .L.A. Hart, THe CONCEPT OF LAW (3d ed. 2012).

${ }^{48}$ See id. at 100-09.

${ }^{49}$ See, e.g., Primus, supra note 8, at 175-76 (treating it as such). 
and attitudes actually prevailing in a given legal culture. It does not in any obvious way turn on the difficulty of constitutional amendment. ${ }^{50}$ Thus, the positivist argument for nonoriginalism, like Sachs's positivist argument for originalism, is properly categorized as exogenous.

\section{Endogeneity}

We now turn our attention to endogenous interpretive arguments. Like exogenous arguments, these arguments may or may not be persuasive. The crucial distinction is that their persuasiveness is affected-positively or negatively-by difficulty of amendment. This endogeneity is their central defining characteristic. ${ }^{51}$

Endogenous arguments for nonoriginalism support the conventional view that stringent amendment procedures make originalism less attractive. Endogenous arguments for originalism attempt to turn the conventional view on its head. A third type of endogenous argument, recently advanced by Aziz Huq, takes a more nuanced position. Under some social and political conditions, a stringent amendment procedure makes originalism more attractive. Under others, it does the opposite. All three types of endogenous argument effectively collapse interpretive choice into a debate over the desirability of supermajoritarian amendment procedures.

\footnotetext{
${ }^{50}$ But see supra note 38.

${ }^{51}$ For ease of exposition, we assume that any endogeneity is continuous and linear, but this need not be the case. The relationship between difficulty of amendment and interpretive choice could be endogenous up to a point but no further. Or that relationship could be positively endogenous across some range and negatively endogenous across another. For instance, increasing the difficulty of amendment might yield diminishing marginal benefits up to some voting threshold, past which the returns of further increases might zero out or become negative. Assuming originalism is necessary to preserve the fruits of supermajoritarianism, it would have a positively endogenous relationship with difficulty of amendment up to this threshold. Past that point, the relationship would become either exogenous (if the returns to supermajoritarianism flat-line) or negatively endogenous (if those returns become negative). Cf. Keith E. Whittington, Against Very Entrenched Constitutions, WISC. L. Rev. 12 (2015) (arguing for a "Goldilocks" approach to difficulty of amendment - not too stringent but not too lenient). This possibility magnifies the potential complexity of the relationship between difficulty of amendment and interpretive choice but does not otherwise affect our analysis.
} 


\subsection{Endogenous Arguments for Nonoriginalism}

Two endogenous arguments are utterly standard elements of the nonoriginalist arsenal. One is the argument from popular sovereignty, sometimes known as the dead-hand argument. The other is the pragmatic argument that constitutional interpretation must be responsive to contemporary problems. The familiarity of these arguments is perhaps the principal reason many constitutional theorists slip so easily into the conventional view. It appears to follow logically from arguments they take largely for granted.

As we examine these arguments more closely, two points bear emphasis. First, as we have already seen, they are not the only arguments for nonoriginalism. Indeed, many of the most important arguments for nonoriginalism are neither bolstered nor undermined by the stringency of Article V-i.e., they are exogenous. Second, both the persuasiveness and the endogeneity of these arguments turns in significant part on contestable empirical assumptions. Thus, even if we accept their normative premises, it is merely plausible rather than certain that they support the conventional view.

\section{a. Popular Sovereignty}

Perhaps the oldest endogenous argument for nonoriginalism, at least as old as the U.S. Constitution itself, sounds in popular sovereignty. A stringent amendment procedure prevents subsequent popular majorities from readily altering the constitution adopted by their political forebears. In the case of the U.S. Constitution, a tiny minority can block constitutional changes supported by large popular majorities. The result is a Constitution imposed by the "dead hand of the past." So stated, the dead-hand problem is an objection to supermajoritarian constitutionalism rather than originalism. ${ }^{52}$ But originalism exacerbates the dead-hand problem by fixing in place the constitutional meaning embraced by long-dead founders who inhabited a radically different

${ }^{52}$ Cf. Letter from Thomas Jefferson to James Madison (Sept. 6, 1789), in 15 JULIAN BOYD, THE PAPERS OF JAMES MADISON 392, 396 (ed., 1958) (“[N]o society can make a perpetual constitution, or even a perpetual law. The earth belongs always to the living generation."). 
world than contemporary Americans.

Many theorists have thought this argument a decisive, even unanswerable, justification for nonoriginalism. ${ }^{53}$ Needless to say, originalists have not been persuaded. ${ }^{54}$ For present purposes, we take no position on this debate. The important point is that the strength of the dead-hand objection is directly tied to the difficulty of constitutional amendment. The more difficult a constitution is to amend, the more likely that its original meaning will be out of step with the views of contemporary majorities, and vice versa. To the extent that popular sovereignty is an important normative criterion, this means that increasing the difficulty of constitutional amendment should decrease the attractiveness of originalism. The dead-hand argument is therefore properly classified as an endogenous argument for nonoriginalism.

One important caveat is in order. The dead-hand argument depends on the contestable empirical assumption that increasing difficulty of amendment will reduce popular support for the Constitution's original meaning. This is certainly a plausible view, but it is far from selfevident. Perhaps public opinion varies randomly over time or follows a cyclical pattern, in which case the original meaning of an old, difficultto-amend constitution is no more likely to enjoy popular support than one that is newer and easier to amend. ${ }^{55}$ If this is the case, difficulty of amendment has no implications one way or the other for interpretive choice. Another possibility is that a difficult amendment process tends to increase public veneration for the constitution by increasing the average age of its provisions. ${ }^{56}$ If this is the case, increasing the difficulty of constitutional amendment might actually make originalism more compatible with popular sovereignty. Again, we take no position on these alternatives. The important point is that the endogeneity of any particular interpretive argument turns on both empirical and normative considerations.

${ }^{3}$ See Coan, Irrelevance, supra note 26, at 1034-35; Primus, supra note 8, at 199.

${ }^{54}$ Michael W. McConnell, Textualism and the Dead Hand of the Past, 66 GEO. WASH. L.

REV. 1127 (1998); Frank H. Easterbrook, Textualism and the Dead Hand, 66 GEO. WASH. L. REV. 1119 (1998); WHITTINGTON, supra note 9, at 155.

${ }^{55}$ Cf. Adam M. Samaha, Originalism's Expiration Date, 30 Cardozo L. Rev. 1295, 1300

(2008) ("If refashioned into a quick take on history, originalism can amount to throwing dice on supreme law.").

${ }^{56}$ Cf. id. at 1303-04 ("[T] he document has become a national icon, which can strangely dampen the use of its own Article V process."); JAMES MADISON, THE FEDERALIST NO. 49, at 313, 314 (Clinton Rossiter ed., 1961) (celebrating "that veneration which time bestows on every thing"). 


\section{b. Adaptation to Changed Circumstances}

A second and similarly influential endogenous argument for nonoriginalism turns on the need to keep constitutional interpretation in tune with the times. Theoretically, constitutional amendment could serve this role, but as the difficulty of amendment increases, the likelihood that it will do so adequately grows smaller and smaller. So stated, this argument, like the dead-hand objection, is an argument against supermajoritarian constitutionalism rather than originalism. But originalism exacerbates the changed-circumstances problem by fixing in place original meanings embraced by earlier generations who faced radically different political, economic, and social conditions.

Like the dead-hand objection, of which it is a close cousin, the changed-circumstances argument has convinced many nonoriginalists. ${ }^{57}$ Originalists have offered a variety of responses, which we need not rehearse here. ${ }^{58}$ The important point is that that the strength of the changed-circumstances objection is directly tied to the difficulty of constitutional amendment. The more difficult a constitution is to amend, the more likely that its original meaning will fail to take account of new circumstances, and vice versa. To the extent that responsiveness to such circumstances is an important normative criterion, this means that increasing the difficulty of constitutional amendment should decrease the attractiveness of originalism. The changed-circumstances argument is therefore properly classified as an endogenous argument for nonoriginalism.

Again, there is an important caveat. The changed-circumstances argument depends on the contestable empirical assumption that increasing the difficulty of amendment will make a constitution's original meaning worse adapted to contemporary circumstances. This is clearly a plausible view, but it is by no means self-evident. Perhaps a lax amendment procedure would lard the constitution with highly precise and rapidly outdated amendments, most of which would remain unaltered through force of inertia. ${ }^{59}$ Or perhaps a lax amendment procedure would undermine the stability of basic institutions necessary

${ }^{57}$ Coan, Talking, supra note 8; Sunstein, Perfectionism, supra note 41; Richard A. Posner, Bork and Beethoven, 42 STAN. L. REV. 1365 (1990).

${ }^{58}$ See, e.g., Strang, supra note 20; Balkin, supra notes 22 and 28.

${ }^{59}$ The constitutions of U.S. states are often thought to suffer from this problem. See AlAN TARR, UNDERSTANDING STATE CONSTITUTIONS 9-10 (1998).

1 JOURNAL OF INSTITUTIONAL STUDIES 1 (2015) 
to make the political process-including the amendment processresponsive to changing circumstances. ${ }^{60}$ Under either of these scenarios, the changed-circumstances argument would remain endogenous, but its endogeneity would run in the opposite direction. That is, increasing the difficulty of amendment would make originalism more attractive than it otherwise would be.

\subsection{Endogenous Arguments for Originalism}

Given the embarrassment many originalists confessedly feel about Article $V^{61}$ it might seem surprising to find them embracing arguments premised on the difficulty of constitutional amendment. Nevertheless, at least two important arguments for originalism fall into this category. The first is really a family of related arguments, encompassing stability, predictability, and rule-of-law values. The second is a consequentialist argument of more recent vintage, advanced by John McGinnis and Michael Rappaport. According to both of these arguments, a difficult constitutional amendment process actually increases the attractiveness of originalism - in fact, is the main justification for it. Of course, if this is true, so is the reverse: A lenient amendment process makes originalism less attractive than it would be under a strict amendment rule. This is the opposite of the conventional view.

\section{a. Stability, Predictability, and the Rule of Law}

One of the most venerable arguments for supermajoritarian amendment procedures is the need to ensure the stability of basic political arrangements over time. ${ }^{62}$ The more difficult a constitution is to amend, the less frequently it is likely to be amended, and the more stable a constitutional order is likely to be. This in turn makes the operation of government and the limits on its authority more easily predictable. It also promotes the strain of rule-of-law values that emphasizes the importance of making social decisions according to

${ }^{60} \mathrm{Cf}$. Stephen Holmes, Precommitment and the Paradox of Democracy, in CONSTITUTIONALISM AND DEMOCRACY 195 (Jon Elster \& Rune Slagstad eds., 1988).

${ }^{61}$ See supra note 7.

${ }^{62}$ See Holmes, supra note 60. 
rules laid down in advance. ${ }^{63}$ So stated, this argument speaks to the desirability of supermajoritarian amendment procedures rather than originalism. But originalism is necessary for the argument to succeed, since it is only originalist interpretation that locks in stable constitutional meanings over time.

As usual, we take no position on the merits of this argument. The important point is that the strength of the stability argument is directly tied to the difficulty of constitutional amendment. The more difficult a constitution is to amend, the more likely that its original meaning will remain stable over time, thereby promoting the virtues of predictability and the rule of law. To the extent that such virtues are normatively significant, this means that increasing the difficulty of constitutional amendment should increase the attractiveness of originalism. The stability argument is therefore properly classified as an endogenous argument for originalism.

Like other endogenous arguments we have discussed, the stability argument rests on contestable empirical foundations. In particular, it rests on the assumption that increasing the difficulty of amendment will increase the stability of a constitutional order over time. Perhaps, however, increasing the difficulty of amendment will require that successful amendments be cast in more open-ended language in order to generate the broad overlapping consensus needed to satisfy stringent amendment procedures. If the original meaning of such language is vague or ambiguous, increasing the difficulty of amendment might actually reduce the attractiveness of originalism relative to a range of plausible alternatives (which might increase the clarity and predictability of constitutional law relative to the vagueness and ambiguity of original meaning). We do not say this is likely, merely that it is possible. The important point, again, is that the endogeneity of any particular interpretive argument has both empirical and normative determinants.

\section{b. Good Consequences}

A second endogenous argument for originalism rests explicitly on the desirable consequences of supermajoritarian amendment procedures. In a recent book and series of articles, John McGinnis and

${ }^{63}$ See McGinnis \& Rappaport, Supermajoritarian, supra note 15, at 784-85; Primus, supra note 8 , at $212-13$. 
Michael Rappaport have argued that supermajoritarian amendment and ratification procedures produce better constitutional rules than majoritarian procedures. ${ }^{64}$ Echoing the voting-rules literature, they emphasize the power of supermajoritarian procedures to protect minority rights, ${ }^{65}$ promote long-term decision-making, ${ }^{66}$ build consensus, ${ }^{67}$ and increase the attention and deliberation afforded to proposed constitutional changes. ${ }^{68}$ All of these benefits, however, require a judicial commitment to originalist interpretation to preserve the fruits of the supermajoritarian amendment process. Indeed, McGinnis and Rappaport go one step further and urge judges to follow "original interpretive methods" - the methods that the original ratifying supermajority would have expected subsequent interpreters to follow. ${ }^{69}$ Only this approach, they contend, accurately captures the constitutional meanings that have received supermajoritarian approval. ${ }^{70}$

Whatever its merits, McGinnis and Rapport's argument is perhaps the most self-consciously endogenous approach we have encountered. The entire point of originalism, as they understand it, is to preserve the benefits associated with a supermajoritarian amendment process. Although they do not draw out this implication, it follows that the case for originalism strengthens as the amendment process becomes more stringent (at least up to a point) ${ }^{71}$ and weakens as the amendment process becomes more lax. In other words, the likelihood that originalism will produce good consequences is higher under a difficult amendment procedure than it is under an easy one.

Like the other endogenous arguments we have discussed, McGinnis and Rapport's position depends in important ways on contestable empirical assumptions. Most notably, it assumes that the difficulty of constitutional amendment has remained constant across American history. In fact, as the number of participants in the amendment process

\footnotetext{
${ }^{64}$ See sources cited at supra note 15.

${ }^{65}$ McGinnis \& Rappaport, Supermajoritarian, supra note 15, at 734-35.

${ }^{66} \mathrm{Id}$. at 784-85.

${ }^{67} \mathrm{Id}$. at 741 .

${ }^{68} \mathrm{Id}$. at $739-40$.

${ }^{69}$ John O. McGinnis \& Michael B. Rappaport, Original Methods Originalism: A New Theory of Interpretation and the Case Against Construction, 103 Nw. U. L. REV. 751 (2009). ${ }^{70} \mathrm{Id}$.

${ }^{71}$ They are careful to acknowledge that, at some point, the returns of supermajoritarianism diminish and may eventually become negative. In other words, even on their rosy view of supermajoritarianism, an amendment process can be too strict, though they do not believe this to be true of Article V. See McGinniss \& Rappaport, supra note 15, at 66-82.
} 
has grown, the practical difficulty of satisfying Article V's amendment procedures has almost certainly grown significantly. ${ }^{72}$ Indeed, recently adopted statutes have likely surmounted more stringent enactment requirements than most $18^{\text {th }}$ - and $19^{\text {th }}$-century constitutional provisions. In preferring the original meaning of the latter to the former, McGinnis and Rappaport may well be deviating from the logic of their own argument. At a minimum, their argument turns on the complicated question of whether, and at what point, the marginal returns of supermajoritarianism run out or turn negative. ${ }^{73}$

\subsection{Aziz Huq's Two-Speed Constitution}

One of the most interesting endogenous arguments in the recent literature is advanced by Aziz Huq. In a nutshell, Huq argues that different constitutional amendment procedures are appropriate for different social and political circumstances. In particular, a new and unstable constitutional order requires stringent procedures to reduce the risk of opportunistic amendment and to encourage investment in the institutions necessary to the new regime's survival. As Huq puts it, “Article V encourages all parties to have 'skin in the game.' A positive feedback mechanism thereby arises, as investment induces confidence, which in turn yields more investment; the prospect of exit recedes from sight." ${ }^{\prime 4}$ Although he does not make the point directly, this dynamic requires judicial interpreters to adopt some form of originalism, to fix the original bargain in place.

As a constitutional system matures, the advantages of a stringent amendment procedure become less salient, while its liabilities loom larger. In the American context, "[w] hat worked in the early Republic to address the peril of hold-up became increasingly dysfunctional in the fluid economic and geopolitical contexts of the late nineteenth, twentieth, and twenty-first centuries."75 At this point in American political development, Huq suggests, the need to adapt an old

72 See Rosalind Dixon \& Richard Holden, Constitutional Amendment Rules: The Denominator Problem, COMPARATIVE CONSTITUTIONAL DESIGN 195 (Tom Ginsburg ed., 2012).

${ }^{73}$ See supra note 51.

${ }^{74}$ Aziz Z. Huq, The Function of Article V, 162 U. PA. L. ReV. 1165, 1172 (2014).

${ }^{75} \mathrm{Id}$. at 1229 . 
constitutional text to radically changed circumstances superseded the benefits of a stringent amendment procedure. In response to these pressures, American judges used flexible, nonoriginalist interpretation as an end-run around the onerous procedures of Article V. This is the second, faster "speed" of Huq's "two-speed Constitution."

Because Huq's focus is on Article V and constitutional amendment more generally, not theories of interpretation, he does not address the implications of his argument for the latter. But those implications are clear enough. At both speeds, the relationship between difficulty of amendment and interpretive choice is endogenous. In the early unstable period of constitutional development, the more difficult the amendment procedure, the greater the importance of originalist interpretation to ensure its rigidity. Once the early risks of constitutional collapse subside, the case for flexible interpretation grows stronger as the formal amendment procedure becomes more difficult, rendering effective textual responses to change less likely. This is simply a time-limited variant on the changed-circumstances argument for nonoriginalism we discussed earlier. What distinguishes Huq's account is his suggestion that the conventional view might obtain for one constitutional epoch and its diametrical opposite for another.

\section{Summing Up}

To review, the complexity thesis holds that difficulty of amendment might or might not affect interpretive choice. Moreover, contrary to the conventional view, increasing the difficulty of amendment might make originalism more attractive rather than less. Much depends on the normative and empirical premises of one's approach to interpretive choice.

In this Part, we have shown that many important arguments for and against originalism are unaffected by difficulty of amendment. The relationship of these arguments to difficulty of amendment is exogenous. Other important arguments for and against originalism are affected by difficulty of amendment. The relationship of these arguments to difficulty of amendment is endogenous. Importantly, this endogeneity runs in both directions. On some normative and empirical premises, increasing the difficulty of amendment makes originalism less attractive, as the conventional view suggests. On other normative and empirical premises, it does the opposite.

For all of these reasons, the conventional view is potentially misleading. It may ultimately be true that the stringency of Article V makes originalism less attractive, but that cannot be demonstrated 
without careful attention to the normative and empirical questions discussed in this Part. Recognizing this complexity in the relation between difficulty of amendment and interpretive choice has substantial implications for a range of important issues. It is to those issues we now turn.

\section{IV.IMPLICATIONS OF COMPLEXITY}

Of what use is the complexity thesis? First, and most straightforwardly, it clarifies the relevance of difficulty of amendment to central debates over interpretive choice. At the very least, this should help constitutional theorists avoid talking past each other. More optimistically, it has the potential to facilitate productive debate over the normative and empirical premises that actually divide different schools of interpretive theory. Second, the complexity thesis illuminates the relationship between statutory interpretation and constitutional interpretation. In particular, it complicates the prevailing view that the extreme difficulty of amending the Constitution makes originalism easier to defend in statutory than in constitutional interpretation. Third, the complexity thesis sheds important light on the under-discussed relationship between federal and state constitutional interpretation. Among other interesting results, the complexity thesis suggests that some endogenous arguments for originalism in federal constitutional interpretation weaken the case for originalism in both statutory and state constitutional interpretation.

\section{Interpretive Choice}

The most basic upshot of the complexity thesis is straightforward: The significance of difficulty of amendment for interpretive choice cannot be resolved - or even profitably discussed-without reference to normative and empirical priors. In particular, the extreme difficulty of amending the U.S. Constitution can serve as neither a sword nor a shield for proponents of exogenous interpretive arguments. Proponents of endogenous arguments, by contrast, can use difficulty of amendment as both a shield and a sword but must be prepared to defend their normative and empirical premises. When proponents of exogenous and endogenous arguments clash, the danger that they will simply talk past 
each other is particularly great. The complexity thesis can help to avoid this. With luck, it should also lead to more productive discussion of the normative and empirical premises that ultimately motivate the disagreement surrounding difficulty of amendment.

\subsection{Difficulty of Amendment and Exogenous Arguments}

The persuasiveness of exogenous arguments is, by definition, unaffected by difficulty of amendment. This point applies to both originalist and nonoriginalist arguments. So while proponents of exogenous arguments for originalism might feel embarrassed by the extreme difficulty of amending the U.S. Constitution, they need not be. If the premises underlying their arguments are true, difficulty of amendment is irrelevant, except insofar as it increases the stakes of getting interpretive choice right. On the other hand, proponents of exogenous arguments for originalism might attempt to draw on Article $V^{\prime}$ 's stringent amendment procedures for support. But they cannot. Difficulty of amendment neither undercuts nor strengthens the case for exogenous interpretive arguments.

Consider the originalist arguments from writtenness, interpretation, and positive law. These are among the most influential contemporary justifications for originalism. And all might be subject to criticism grounded in the conventional view that the stringency of Article $\mathrm{V}$ makes originalism less attractive. Indeed, some of the most astute proponents of these arguments appear to believe-or at least to harbor suspicions - that this is the case. ${ }^{76}$ But if any of these arguments is correct, the conventional view must be wrong. The reason is simple. Increasing the difficulty of constitutional amendment does not alter the concept of interpretation, the nature of writtenness, or the rule of recognition governing American constitutional law. If any of these entails originalism, that is the approach judges should adopt under any amendment regime, no matter how stringent.

The same analysis applies to exogenous arguments for nonoriginalism with the opposite result. Consider the nonoriginalist arguments from moral philosophy, representation reinforcement, and positive law. Like their originalist counterparts, these exogenous arguments are among the most influential contemporary justifications for originalism. And like nonoriginalism generally, all might plausibly seek support in the conventional view. Indeed, their proponents routinely advance some form of that view in making the case for

${ }^{76}$ See sources cited at supra note 7. 
nonoriginalism. But if any of these arguments is correct, the conventional view must be wrong. Again, the reason is simple. Increasing the difficulty of amendment does not affect the moral attractiveness, the representative character, or the inconsistency of original meaning with positive law. If any of these entails nonoriginalism, that is the approach judges should adopt under any amendment regime, no matter how lenient.

The upshot is that proponents of exogenous arguments can, for most purposes, ignore difficulty of amendment. In particular, they can safely disregard the conventional view, which neither supports nor weakens their case. Indeed, if they are right, the conventional view is necessarily wrong. It is the complexity thesis that leads to this insight.

\subsection{Difficulty of Amendment and Endogenous Arguments}

The persuasiveness of endogenous arguments, by contrast, is affected by difficulty of amendment. It follows that proponents of endogenous arguments can use the extreme difficulty of amending the U.S. Constitution as both a sword and a shield. But to do so, they must be prepared to defend the normative and empirical premises necessary to make their arguments persuasive.

Consider the nonoriginalist arguments from popular sovereignty and adaptation to changed circumstances. If sound, these arguments support the conventional view that the stringency of Article $\mathrm{V}$ makes originalism less attractive. But their soundness depends on a variety of controversial normative and empirical premises. If popular sovereignty and adaptation to changed circumstances are not important normative criteria, or if neither is compromised by difficult amendment procedures coupled with originalism, then these endogenous arguments provide no support for the conventional view. Put differently, the conventional view depends on the validity of particular arguments in favor of nonoriginalism. As such, theorists would do better to focus on those arguments, rather than difficulty of amendment in the abstract.

The same analysis applies to endogenous arguments for originalism but with the opposite result. Consider the originalist arguments from stability and good consequences. If sound, these arguments refute the conventional view that Article $\mathrm{V}$ makes originalism less attractive. Indeed, if they are sound, the stringency of Article $\mathrm{V}$ actually makes originalism more attractive. But like their nonoriginalist counterparts, the soundness of these endogenous arguments for originalism depends 
on a variety of controversial normative and empirical premises. If legal stability and good consequences are not important normative criteria, or if neither is promoted by difficult amendment procedures, then Article $\mathrm{V}$ does not increase the attractiveness of originalism. Put differently, the relationship between originalism and Article $\mathrm{V}$ depends on the validity of particular originalist arguments. Again, theorists would do better to focus on those arguments, rather than difficulty of amendment in the abstract. The complexity thesis creates room for this more fine-grained discussion.

\subsection{Exogenous vs. Endogenous Arguments}

Perhaps the greatest risk of confusion arises when exogenous and endogenous arguments clash. Under the conventional view, which treats the relationship between difficulty of amendment and interpretive choice as a simple, universal one, such clashes are highly likely to be unproductive on both sides. Proponents of exogenous arguments frequently fail to appreciate that their normative premises make difficulty of amendment irrelevant. Meanwhile, proponents of endogenous arguments fail to appreciate the importance of their normative and empirical premises to the validity of the conventional view. As a result, the opposing sides frequently fail to join issue on the real sources of their disagreement.

Consider a clash between the originalist argument from interpretation or writtenness and the nonoriginalist argument from popular sovereignty. The former insists that the concept of interpretation or writtenness compels an originalist approach to constitutional interpretation, preclusive of all other normative considerations. The latter treats popular sovereignty as the paramount normative criterion and assumes that originalism-coupled with a stringent Article $\mathrm{V}$ amendment procedure-thwarts the sovereignty of contemporary citizens. Their disagreement boils down to (1) the correct normative criterion for evaluating interpretive choice and (2) the empirical relation of that criterion to difficulty of amendment. Without an understanding of the complexity thesis, however, proponents of these views are likely to argue over difficulty of amendment in the abstract, without reference to the actual sources of their disagreement.

The complexity thesis lays those sources bare. At a minimum, this substantially reduces the likelihood that the two sides will simply talk past each other. More optimistically, it establishes the foundation for a productive discussion of the normative and empirical premises at issue. 


\section{Statutory vs. Constitutional Interpretation}

To an uninitiated observer, statutory and constitutional interpretation must surely seem to have much in common. Both are concerned with making sense of-and giving effect to-authoritative legal texts. Both are, paradigmatically though far from exclusively, performed by unelected federal judges with life tenure. And in both cases, the authoritative legal texts in question are (or were) drafted and voted on by democratically elected multi-member bodies.

Yet for all this apparent overlap, the academic literatures on statutory and constitutional interpretation basically operate in parallel. ${ }^{77}$ A central reason for this curious disjunction is the view that the extreme difficulty of amending the Constitution makes originalism easier to defend in statutory than in constitutional interpretation. The complexity thesis undermines that view, suggesting that constitutional and statutory interpretation have more in common - and diverge in different and more interesting ways - than has been commonly understood.

\subsection{The Lay of the Land}

The principal division among theorists of statutory interpretation is between textualists and intentionalists. The principal question that divides them is whether judges should consult legislative history as a guide to ascertaining the meaning of statutory text. In this sense, most theories of statutory interpretation may be broadly characterized as originalist. Intentionalists believe the proper object of statutory interpretation is the intent or purpose of the enacting legislature, while textualists believe it is the objective public meaning of the statutory text. But for the most part, both agree that the relevant meaning is fixed at the time of enactment.

Among constitutional theorists, the lines of division are very different. Rather than implacable foes, textualism and intentionalism are generally recognized as close cousins-so much so that practicing judges often treat them as interchangeable. Academics are generally more careful, and textualist and intentionalist theorists do have real

77 The two most notable exceptions are William Eskridge and John Manning, whose work we discuss at infra notes $77 \& 82$.

1 JOURNAL OF INSTITUTIONAL STUDIES 1 (2015) 
disagreements. But for the most part, these are minor family quarrels. What unites textualist and intentionalist constitutional theorists is more important than what divides them. And what unites them is the commitment shared by most theorists of statutory interpretation: that the relevant meaning - the meaning judges ought to follow in deciding constitutional cases - is fixed at the time of enactment.

This is not to suggest that constitutional theorists are a picture of harmony. To the contrary, the divisions among theorists of constitutional interpretation are, if anything, deeper and more rancorous than the divisions among theorists of statutory interpretation. The principal lines of division, however, are between originalist theories and nonoriginalist theories, rather than among competing versions of originalism.

This is striking for two reasons. First, two theories that are regarded as virtual opposites in the context of statutory interpretationtextualism and intentionalism-are regarded as close cousins in constitutional interpretation. Second, the most prominent approach in constitutional theory - nonoriginalism - is nearly unrepresented among theorists of statutory interpretation. ${ }^{78}$ The complexity thesis has relatively little to say about the former, but much to say about the latter. ${ }^{79}$

\subsection{Divergence or Convergence?}

More than three decades ago, Richard Posner wrote that "virtually everyone who writes on the question thinks that constitutional provisions should not be construed as strictly as statutory provisions." 80 While Judge Posner cited no authority for this proposition, we have little reason to doubt its continuing validity. Indeed, we suspect that it applies with equal vigor to those who do not write on the question. To be

78 There are important exceptions. See, e.g., William N. Eskridge, Dynamic Statutory Interpretation, 135 U. PA. L. REV. 1479, 1496 (1987); EINER ELHAUGE, STATUTORY DEFAULT RULES: HOW TO INTERPRET UNCLEAR LEGISLATION (2008); Alexander Aleinikoff, Updating Statutory Interpretation, 87 MICH. L. REV. 20 (1988).

${ }^{79}$ This explains our failure to mention some of the most hotly debated arguments in statutory interpretation, many of which speak to the intra-originalist contest between intentionalism and textualism, rather than the contest between originalism and nonoriginalism.

${ }^{80}$ Richard A. Posner, Economics, Politics, and the Reading of Statutes and the Constitution, 49 U. CHI. L. REV. 263, 282 (1982). 
sure, the notion of construing a legal document "strictly" is not identical to interpreting it in an originalist fashion. But Posner's point can be easily adapted for our purposes: Most commentators and judges believe that originalism is more appropriate in statutory interpretation than in constitutional interpretation.

Scholars and courts have offered numerous arguments for this "interpretive divergence." ${ }^{11}$ Unlike statutes, the Constitution is a foundational legal instrument, intended to endure for the ages. ${ }^{82}$ Also unlike statutes, the Constitution establishes the basic structure of government. Constitutional provisions are also usually older and more abstract-and thus more vague - than statutes. Finally, and for our purposes most important, the Constitution is substantially more difficult to amend. ${ }^{83}$

Most of these arguments are generalizations that fail to hold in all cases. ${ }^{84}$ For example, the 1965 Voting Rights Act is surely more fundamental and of greater structural significance than the 24th Amendment's prohibition on poll taxes. It is also of approximately the same vintage, and many of its provisions are no less vague. Likewise, the Sherman Antitrust Act is both older and less precise than the

${ }^{81}$ We borrow this term from Kevin Stack. See Kevin Stack, The Divergence of Constitutional and Statutory Interpretation, U. COLO. L. REV 75 (2004).

82 See, e.g., McCulloch v. Maryland, 17 U.S. 316, 407 (1819) ("In considering this question, then, we must never forget, that it is a constitution we are expounding."); The Legal Tender Case, 110 U.S. 421, 439 (1884) ("A constitution, establishing a frame of government, declaring fundamental principles, and creating a national sovereignty, and intended to endure for ages and to be adapted to the various crises of human affairs, is not to be interpreted with the strictness of a private contract."). But cf. ESKRIDGE \& FEREJOHN, A REPUBliC OF STATUTES: THE NEW AMERICAN CONSTITUTION 1-9 (2010).

${ }^{83}$ See generally Kent Greenawalt, Constitutional and Statutory Interpretation, in THE OXFORD HANDBOOK OF JURISPRUDENCE AND PHILOSOPHY OF LAW (Jules L. Coleman, Kenneth Einar Himma, and Scott J. Shapiro eds., 2004) 269, 289; John F. Manning, The Eleventh Amendment and the Reading of Precise Constitutional Texts, 113 YALE L.J. 1663, 1693 (2004). Related to both age and vagueness, though theoretically distinct, is the difficulty of determining original meaning. See Coan, Talking Originalism, supra note 8 , at 113.

${ }^{84}$ Most are also plausibly endogenous to difficulty of amendment: all else equal, legal norms that are more difficult to amend seem likely to be more deeply rooted, older, and more abstract. 
Sixteenth Amendment. These and other similar examples have led William Eskridge and John Ferejohn to coin the term "superstatutes" and to buck the conventional wisdom of interpretive divergence, at least where this special breed of statutes is involved..$^{85}$

By contrast, the argument from difficulty of amendment precisely tracks the difference between statutes and constitutional provisions. Amending any statute is easier than amending any constitutional provision. ${ }^{86}$ This explains why difficulty of amendment has typically been thought a particularly robust argument for interpretive divergence-both normatively and descriptively. ${ }^{87}$ That argument, however, depends directly on the conventional view, which as Parts I and II demonstrated, rests on highly contestable-and actively contested-normative and empirical premises. It goes something like this:

1. Major Premise: The more difficult a legal instrument is to amend through formal procedures, the weaker the argument in favor of an originalist interpretive methodology.

2. Minor Premise: The Constitution is more difficult to amend than federal statutes. ${ }^{88}$

3. Conclusion: The argument for originalism is weaker in constitutional than in statutory interpretation.

The complexity thesis, of course, undermines the major premise of this syllogism. More precisely, it suggests that the truth of the major premise depends on highly contested assumptions, both theoretical and empirical-assumptions that we disentangled in Part III. In this way,

${ }^{85}$ See generally ESKRIDGE \& FEREJOHN, supra note 82.

86 The only Article V procedure ever successfully used to amend the Constitution requires a veto-proof majority of both houses of Congress plus ratification by threefourths of state legislatures, making the procedure for passing legislation virtually a strict subset of the Article V procedures for amendment. U.S. CONST. Art. V.

${ }^{87}$ See, e.g., Stack at 5-6 (arguing that the fact that "the prospect of formal override of the Supreme Court's constitutional decisions is much more remote than statutory overrides" undermines the argument that legal stability favors interpretive convergence).

${ }^{88}$ Although the minor premise may be assumed to be true for our purposes here, the passage of time complicates things. Mathematically - and perhaps even practically-it may be more difficult to pass a statute today than it was to pass a constitutional amendment in the late 18 th or early 19 th century. See Dixon \& Holden, supra note 72 , at $1-2$. 
the complexity thesis clarifies when and whether interpretive divergence is normatively desirable.

\subsection{The Complexity Thesis Applied}

The upshot of the complexity thesis for interpretive divergence is straightforward. Every endogenous argument in constitutional interpretation, whether originalist or nonoriginalist, implies divergence between statutory and constitutional interpretation. Exogenous arguments, by contrast, imply convergence. More precisely, endogenous arguments imply that the strength of originalist and nonoriginalist arguments will differ between these two domains, all else being equal, while exogenous arguments imply that their strength will be the same across both domains, again all else equal. ${ }^{89}$

This means the conventional wisdom about statutory and constitutional interpretation-like the conventional view about difficulty of amendment and interpretive choice-could be right. On several plausible normative and empirical premises, the case for originalism is stronger in statutory than in constitutional interpretation. But on several other plausible premises, the strength of interpretive arguments across these domains is identical. On still other plausible premises, precisely the opposite is the case: that is, the case for originalism is weaker in statutory than in constitutional interpretation. In highlighting these alternative possibilities, the complexity thesis breaks genuinely new ground.

Consider the originalist arguments from writtenness and the concept of interpretation. Both turn on characteristics that statutes and constitutions share-both are written documents that judges are

${ }^{89}$ The "all else equal" caveat is important. While our focus is difficulty of amendment, other differences between statutory and constitutional interpretation might offset or even outweigh its impact. For example, if an easier amendment process favors nonoriginalism but precise language even more strongly favors originalism, the latter might swamp the former, making the overall case for originalism stronger in statutory than in constitutional interpretation, even though the effect of difficulty of amendment considered in isolation is the opposite. The same goes for exogenous arguments: Even if difficulty of amendment makes no difference to interpretive choice-and thus implies convergence-other differences might cause statutory and constitutional interpretation to diverge. 
supposed to interpret. If either of these characteristics entails originalism in constitutional interpretation, it also entails originalism in statutory interpretation. The fact that statutes are easier to amend than constitutional provisions has no effect on the nature of writtenness or the concept of interpretation and therefore no effect on the originalist arguments from these premises. Put differently, if the arguments from writtenness and the concept of interpretation are persuasive, statutory and constitutional interpretation should converge.

The same analysis applies to exogenous arguments for nonoriginalism. Consider the moral-reading argument for nonoriginalism. This argument turns on a Dworkinian understanding of the law as the set of principles that best fits and justifies the authoritative legal materials. This understanding of law embraces statutes as well as constitutional provisions. If it entails a nonoriginalist approach to the latter, it entails the same approach to the former. The fact that statutes are easier to amend than constitutional provisions has no effect on the Dworkinian understanding of law and therefore no effect on the nonoriginalist argument from these premises. If that argument is correct, statutory and constitutional interpretation should converge.

By contrast, endogenous arguments for and against originalism both produce interpretive divergence, albeit in opposite directions. Endogenous arguments for nonoriginalism entail the conventional wisdom, that the argument for originalism is stronger for statutory interpretation than constitutional interpretation. On the other hand, endogenous arguments for originalism imply-interestingly and counter-intuitively-that the case for originalism is stronger for constitutional interpretation than statutory interpretation.

Consider the originalist argument from good consequences..$^{90}$ More than any other argument we have discussed, this one is proudly, explicitly endogenous to difficulty of amendment. That is, the argument that originalism will produce good consequences-by encouraging long-term thinking, compelling respect for minority rights, etc. - grows stronger as the amendment process becomes more difficult. In effect, the argument is that originalism is desirable because it is necessary to capture the benefits of a stringent super-majority amendment procedure. Since the Constitution is more difficult to amend than federal statutes, this argument for originalism is stronger for the former than the latter. ${ }^{91}$

90 See Part III, 2.2., b, supra.

${ }^{91}$ John Manning, who endorses a somewhat different endogenous argument for originalism, actually makes this point explicitly. See Manning, supra note 83, at id. at 
The same analysis applies to endogenous arguments for nonoriginalism but with the opposite result. Consider the nonoriginalist argument from popular sovereignty, sometimes referred to as the deadhand objection. Like the originalist argument from good consequences, this argument grows stronger as difficulty of amendment increases. In effect, the argument is that nonoriginalism is desirable because it is necessary to overcome the democratic defects of a stringent supermajority amendment procedure. The same goes for the nonoriginalist argument from changed circumstances, which contends that nonoriginalism is desirable because it is necessary to overcome the inflexibility of Article V. Since statutes are easier to amend than the Constitution, both of these arguments for nonoriginalism are stronger for the latter than the former..$^{92}$

In sum, only endogenous arguments for nonoriginalism are consistent with the conventional wisdom that the extreme difficulty of amending the Constitution makes originalism easier to defend in statutory than in constitutional interpretation. Exogenous arguments for both originalism and nonoriginalism imply that interpretive choice should converge across the two domains. And endogenous arguments

1701 (" $[\mathrm{T}]$ he Court has, if anything, a more obvious duty to respect the boundaries set by a constitutional rather than statutory test-at least when the text is clear and precise in context."). Interestingly, Michael Ramsey has expressed something like the opposite view: [I]f you're not a constitutional originalist, you need either to explain why statutory originalism ... is wrong, or you need to explain why constitutional originalism is different from statutory originalism. I'm not saying that either can't be done, but they aren't done very often. Michael Ramsey, "Victoria Nourse on Legislative History," The Originalism Blog, February 11, 2015, at $<$ http://originalismblog.typepad.com/the-originalism-blog/2015/02/victoria-nourse-theconstitution-and-legislative-history-michael-ramsey.html>. Under the views of Manning and McGinnis \& Rappaport, Ramsey has it exactly backward: If you are a constitutional originalist because of Article V's stringent supermajoritarianism, you need to explain why statutory interpretation should be approached the same way as constitutional interpretation, despite the vastly less stringent procedures for statutory change. It's not that the two views are irreconcilable, but some explanation is required. ${ }_{92}$ Again, this does not strictly entail divergence. The case for nonoriginalism could be weaker for statutory than constitutional interpretation but still stronger than the plausible alternatives. Cf. William Eskridge, Dynamic Statutory Interpretation, 135 U. PA. L. REV. 1479, 1496 (1987) (arguing for a dynamic approach to both kinds of interpretation based in part on an argument from changed circumstances).

1 JOURNAL OF INSTITUTIONAL STUDIES 1 (2015) 
for originalism imply precisely the opposite of the conventional wisdom - that the extreme difficulty of amending the Constitution makes originalism easier to defend in constitutional than in statutory interpretation. This should give constitutional theorists and theorists of statutory interpretation plenty to talk about.

\section{State vs. Federal Constitutional Interpretation}

Like statutory and constitutional interpretation, state and federal constitutional interpretation would seem to have much in common. Both involve making sense of - and giving effect to-authoritative legal texts that are principally concerned with constituting the basic institutions of government and protecting fundamental civil liberties. Indeed, many state constitutions borrow much of their language directly from the U.S. Constitution. Interpretation of the latter, however, is the subject of a vast literature, while constitutional theorists have generally ignored state constitutions, ${ }^{93}$ despite growing recognition of their central importance to the American legal order. ${ }^{94}$

Although we cannot prove it, we suspect this state of affairs reflects a widespread assumption that state constitutional interpretation is little different from federal constitutional interpretation..$^{95}$ This is essentially

\footnotetext{
${ }_{93} \mathrm{Jim}$ Rossi, Assessing the State of State Constitutionalism, 109 MicH. L. Rev. 1145 (2011) ("State constitutions are very important legal documents, but their interpretation is remarkably understudied (and, of course, highly under-theorized) in the academic literature."); Jack L. Landau, Some Thoughts About State Constitutional Interpretation, 115 PenN St. L. Rev. 837, 838 (2011) (“Little attention has been paid to state constitutional interpretive method or theory, however."); Daniel B. Rodriguez, State Constitutional Theory and Its Prospects, 28 N.M. L. REV. 271, 272 (1998) ("[O]ne of the most arresting features of modern state constitutional jurisprudence is that there are no distinct theoretical paradigms that shape state constitutional theory."). There are, of course, exceptions. See, e.g., JAMES A. GARDNER, INTERPRETING STATE CONSTITUTIONS (2005); Robert F. Williams, Interpreting State Constitutions As Unique Legal Documents, 27 OKLA. CiTY U. L. REV. 189, 190 (2002).

94 See, e.g., EMILy Zackin, LOOKIng For Rights in All the WrOng Places: Why State CONSTITUtions Contain AMERICA's Positive Rights (2014); Mila Versteeg \& Emily Zackin, American Constitutional Exceptionalism Revisited, 81 U. CHI. L. REV. 1641 (2014); SANFORD LEVINSON, FRAMED: AMERICA'S 51 CONSTITUTIONS AND THE CRISIS OF GOVERNANCE (2012).

95 See Rodriguez, supra note 93 ("We borrow whole cloth from federal constitutional theory when we interpret state constitutions."); cf. Williams, supra note 93 ("Federal
} 
the opposite of the conventional wisdom about statutory and constitutional interpretation but equally problematic. Instead of overestimating the differences between federal and state constitutional interpretation, the conventional wisdom underestimates them, including difficulty of amendment. The complexity thesis offers a necessary corrective, suggesting that federal and state constitutional interpretation have less in common-and converge in different and more interesting ways - than has been commonly understood. ${ }^{96}$

The analysis here closely tracks our analysis of statutory and constitutional interpretation, with state constitutions taking the place of statutes. Because state constitutions are significantly easier to amend than the U.S. Constitution, endogenous interpretive arguments imply divergence between federal and state constitutional interpretation. Exogenous arguments, for the most part, imply convergence. ${ }^{97}$ More precisely, the strength of endogenous arguments will differ between federal and state constitutional interpretation, all else equal, while the strength of exogenous arguments will generally be the same across both domains. $^{98}$

constitutional law has received the lion's share of academic and judicial analysis within the category of constitutional interpretation."); Hans A. Linde, State Constitutions Are Not Common Law: Comments on Gardner's Failed Discourse, 24 RUTGERS L.J. 927, 933 (1993) ("General constitutional law courses, which everyone takes, create the impression that contemporary majority opinions and dissents in the United States Supreme Court exhaust the terms as well as the agenda of constitutional litigation."). ${ }^{96}$ Hans Linde speculatively raised the possibility that difficulty of amendment might affect state constitutional interpretation some thirty years ago.See Hans A. Linde, E Pluribus--Constitutional Theory and State Courts, 18 GA. L. REV. 165, 198 (1984) ("Does a constitution properly mean something different in a state where amendment is difficult from one where voters can initiate an amendment simply by collecting a few more signatures than for a statute?"). So far as we can tell, however, no scholar has taken it up in a sustained fashion.

${ }^{97}$ The positivist argument for originalism is consistent with convergence but ultimately turns on whether the social conventions of states treat originalism as part of its positive law. This is an empirical question, the answer to which may well vary by state. See Part III, 1.2., supra.

${ }_{98}$ On the importance of "all else equal," see supra note 89 . There are several important differences between the U.S. and state constitutions beyond difficulty of amendment. The two that have received greatest attention in the recent literature are (1) the role of states as constituent units in a federal regime and (2) the direct borrowing of

1 JOURNAL OF INSTITUTIONAL STUDIES 1 (2015) 
This means the conventional wisdom could be right. On several plausible normative and empirical premises, there is no change in the relative strength of interpretive arguments across federal and state constitutional interpretation. But on several other plausible premises, the case for originalism is stronger in state than in federal constitutional interpretation. On still other plausible premises, precisely the opposite is the case: the case for originalism is weaker in state than in federal constitutional interpretation. The upshot is that state constitutional interpretation cannot simply be casually assimilated to federal constitutional interpretation. A more nuanced approach, sensitive to the crucial importance of normative and empirical priors, is required. In making this point, we join the small band of state constitutional theorists who have, for more than two decades, argued for a distinctive theory of state constitutional interpretation..$^{99}$

Since this analysis so closely tracks our analysis of statutory and constitutional interpretation, we will not belabor it with unnecessary illustrations. Two of its implications, however, are sufficiently important to bear special mention. First, endogenous arguments for nonoriginalism, like the argument from changed circumstances and the dead-hand objection, are weaker for state than for federal constitutional interpretation. If we accept the normative and empirical premises of these arguments, the case for originalism is stronger for state than for

constitutional provisions from other states and the U.S. Constitution. See James A. Gardner \& Jim Rossi, Foreword: The New Frontier of State Constitutional Law, 46 WM. \& MARY L. REV. 1231, 1232 (2005); Williams, supra note 93, at 217. The conflict between originalism and nonoriginalism, however, remains central to state constitutional interpretation. Compare Earl M. Maltz, James Gardner and the Idea of State Constitutionalism, 24 RUTGERS L.J. 1019, 1019 (1993) (endorsing an originalist approach to state constitutional interpretation); Stranahan v. Fred Meyer, Inc., 331 Or. 38, 11 P.3d 228 (2000) (same); with Robert A. Schapiro, Identity and Interpretation in State Constitutional Law, 84 VA. L. REV. 389, 393 (1998) (advocating a nonoriginalist approach); State v. Hemenway, 353 Or. 129, 154, 295 P.3d 617, 632 vacated, 353 Or. 498, 302 P.3d 413 (2013) (Landau, J., concurring) (advocating a nonoriginalist approach). On this issue, the most important theoretical arguments are those developed in connection with the U.S. Constitution, and for many of those arguments, difficulty of amendment looms large.

${ }_{99}$ See Gardner, supra notes 93 and 98; Williams, supra note 93; Schapiro, supra note 98. We are, however, the first to make this point in connection with difficulty of amendment. This is crucial because, more than any other difference between state and federal constitutions, difficulty of amendment is central to the theories of federal constitutional interpretation that still dominate the field. 
federal constitutional interpretation. Second, endogenous arguments for originalism, like McGinnis and Rappaport's argument from good consequences, are weaker for state than for federal constitutional interpretation. If we accept the normative and empirical premises of these arguments, the case for nonoriginalism is stronger for state than for federal constitutional interpretation. ${ }^{100}$

To be clear, this does not mean that McGinnis and Rappaport are compelled to embrace nonoriginalism in state constitutional interpretation nor that proponents of the dead-hand objection are compelled to embrace originalism. The case for originalism (or nonoriginalism) might be weaker in state than in federal constitutional interpretation but still stronger than the plausible alternatives. But the central role that difficulty of amendment-and in particular Article Vplays in these influential accounts of federal constitutional interpretation suggests that the conventional wisdom about state constitutional interpretation requires careful reexamination. Such an effort is beyond the scope of this Article but would be a worthy contribution to the burgeoning literature on state constitutional law.

\section{EVEN MORE COMPLEXITY}

Up to this point, we have assumed a judicial interpreter and a political amendment process. We now relax that assumption, which compels us to address two complicating questions. First, and most basically, how would our analysis change if different institutions performed the functions of constitutional interpretation and constitutional amendment? Second, what role, if any, do considerations of comparative institutional competence play in defining the relationship between difficulty of amendment and interpretive choice? This Part also addresses a third complicating question, unrelated to our

100 We could make a similar point about the relation between U.S. and foreign constitutional interpretation. Nearly every other constitution in the world is easier to amend than the U.S. constitution, so the analysis would precisely track our analysis of federal and state constitutional interpretation, including all the relevant caveats. See sources cited at supra note 98 . But originalism plays so little role in the interpretation of most foreign constitutions that taking this on here would draw us too far afield. See Coan, Irrelevance, supra note 26, at 1066-71. We hope to return to the comparative question in future work. 
assumption of a judicial interpreter: How, if at all, does interpretive choice affect the difficulty of constitutional amendment? We conclude that none of these complications undermines the complexity thesis. Each, however, has the potential to alter the normative and empirical inputs to which the thesis applies.

\section{Institutional Assumptions}

Most of the scholarly literature on interpretive choice assumes that interpretation is done by judges. And of course, the amendment procedures established by Article V are fundamentally legislative-and thus political - in character. Hence our decision to assume a judicial interpreter and a political amendment process in the preceding discussion. There is, however, nothing necessary or inevitable about this allocation of institutional responsibility. Political actors, both executive and legislative, can and do engage in constitutional interpretation. As for amendment procedures, we know of no modern constitutional system in which they are not, in some sense, political. But nonpolitical amendment procedures are certainly conceivable.

Would such a radical reshuffling of institutional responsibility undermine the complexity thesis? In a word, no. To see why, assume that the supreme interpretive authority is a political actor-say, the President-and that the constitutional amendment authority is judicial-say, the U.S. Supreme Court. Under such a regime, the basic relation between difficulty of amendment and interpretive choice would remain unchanged. Starting from any of the exogenous arguments we have discussed, the case for originalism (or nonoriginalism) would be no stronger or weaker if 5 votes on the U.S. Supreme Court were required to amend the Constitution than it would be if 9 votes were required. Starting from any of the endogenous arguments we discussed, there is a good chance the strength of the case for originalism (or nonoriginalism) would vary with the judicial vote threshold, though perhaps in different ways and for different reasons.

Consider, for example, the view that contemporary public opinion should be an important factor in choosing an interpretive approach. Starting from that premise, an increase in the number of judicial votes required to amend the Constitution might make originalism less attractive by systematically decreasing the alignment between public opinion and original meaning. Or it might not. The important point is that the same sort of endogenous relationship can exist between difficulty of amendment and interpretive choice under any allocation of institutional responsibility. Whether such a relationship exists in any 
particular case will depend on both normative and empirical considerations - in our example, whether contemporary public opinion is an important normative criterion and whether a higher vote threshold reduces the empirical likelihood that a judicial amendment process will be responsive to contemporary popular majorities.

To hammer the point home, one more, rather fanciful example may be helpful. In place of a judicial interpreter, assume that the supreme interpretive authority is an ordinary citizen chosen every five years by lot. In place of a political amendment procedure, assume that the constitutional amendment authority is a high-powered computer programmed to generate new constitutional amendments at random (some but not all of which would override the decisions of the authoritative citizen interpreter). Needless to say, this would be an unfortunate system - and radically different from the one we have considered thus far. But how, if at all, would changes in the frequency of random computer-generated amendments-the equivalent of difficulty of amendment-affect interpretive choice?

Again, at the highest level of generality, the answer is not at all. As under a judicial amendment procedure, some interpretive arguments would be exogenous to difficulty of amendment and some would be endogenous, though it is not as easy to imagine what endogeneity might look like in this context. At least in theory, though, changes to the frequency of computer-generated amendments might affect persuasiveness of different interpretive approaches. The strength of exogenous arguments would be no different under a low-frequency amendment protocol (the equivalent of a difficult political amendment procedure) and a high-frequency protocol (the opposite). The strength of endogenous arguments, by contrast, would be sensitive to variations in the frequency of the amendment protocol. This is all the complexity thesis entails.

At a lower level of generality, interpretive choice would look quite different under such a foreign allocation of institutional responsibility. To begin with, the normative and empirical premises underlying most familiar interpretive arguments would be seriously scrambled. To cite just three examples, the popular sovereignty and changedcircumstances arguments for nonoriginalism would lose much of their force, as would the good-consequences argument for originalism. The reason is straightforward. The popular sovereignty and changedcircumstances arguments depend on a negative correlation between original meaning and public opinion that would no longer exist under a regime of random computer-generated amendments. The good 
consequences argument depends on a positive correlation between original meaning and supermajoritarian preferences at the time of enactment that would also no longer exist.

The types and sources of endogeneity would also be quite different from those identified in Part III. No longer would a difficult-i.e., lowfrequency-amendment procedure reduce the likelihood that original meaning would be well-adapted to contemporary circumstances or track contemporary public opinion. Nor would it increase the likelihood that original meaning reflected a broad social consensus, long-term view, or respect for minority rights. Rather, these relationships would be entirely random. Indeed, of all the endogenous arguments surveyed in Part III, only the stability argument for originalism might plausibly hold under a random amendment procedure. ${ }^{101}$

All of this illustrates what we said at the outset of this Part. Altering the institutional allocation of interpretive and amendment authority has the potential to alter the normative and empirical inputs to which the complexity thesis applies. It does nothing, however, to undermine the complexity thesis itself, which holds for any and all allocations of institutional authority.

\section{Comparative Institutional Competence}

We agree with Cass Sunstein and Adrian Vermeule that the central question of interpretive choice is not "how, in principle, should a text be interpreted?' The question instead is 'how should certain institutions, with their distinctive abilities and limitations, interpret certain texts?'" 102 It follows that interpretive choice depends as much or more on

101 The lower the frequency of random amendments, the greater the tendency of an originalist interpretation of those amendments to promote constitutional stability. We do not suggest that this is an incontrovertible or a priori truth, merely a plausible empirical assumption.

102 Cass R. Sunstein \& Adrian Vermeule, Interpretation and Institutions, $101 \mathrm{MICH}$. L. REV. 885, 886 (2003). Sunstein and Vermeule owe a large debt to NEIL KOMESAR, IMPERFECT ALTERNATIVES (1994), and they all owe a huge debt - as do we-to HENRY M. Hart, Jr. \& Albert M. SACKS, The Legal Process: Basic Problems in the MAKING AND APPLICATION OF THE LAW (William N. Eskridge, Jr. \& Philip P. Frickey eds., 1994). See also William Eskridge, No Frills Textualism, 119 HARV. L. REV. 2041, 2045-46 (2006) (reviewing ADRIAN VERMEULE, JUdGING UNDER UNCERTAINTY (2006)) (crediting Henry Hart as one of the earliest legal process theorists that Vermeule builds upon but then criticizes). 
questions of comparative institutional competence as it does on firstbest theories of interpretation.

Indeed, many influential approaches to interpretive choice explicitly incorporate institutional considerations. For example, Ronald Dworkin's moral-reading approach rests in part on an elevated view of the reflective and deliberative capacities of judges. And John Hart Ely's representation reinforcement theory is largely premised on the relative insulation of courts from ordinary politics. Even interpretive arguments that are not self-consciously institutional typically assume that judges are the relevant interpretive authorities and also that judges will do best by pursuing the proper object of interpretation directly. In so doing, they implicitly (and perhaps inadvertently) take a position on the question of comparative institutional competence-namely, that judges are better suited to the interpretive task than the available institutional alternatives.

What does this mean for the complexity thesis? Again, in a strict sense, the answer is nothing. For any given institutional actor, the correct approach to interpretive choice depends on its competence relative to the plausible institutional alternatives. Once that approach is established, however, the complexity thesis applies in full force. Judges (or any other institutional interpreter) should adhere to the same interpretive approach under any amendment procedure unless the normative or empirical premises underlying that approach are endogenous to difficulty of amendment.

For example, assume that original meaning is the positive law of the American constitutional system and that judges will best approximate original meaning by pursuing it directly. Since Part III has already established that the positivist argument for originalism is exogenous to difficulty of amendment, the question would seem to be settled: Taking these premises as given, judges should adopt an originalist approach to constitutional interpretation under any amendment procedure. There is, however, one possibility that we did not explore in Part III: The comparative institutional competence of judges-like other normative and empirical premises of interpretive choice-may be endogenous to difficulty of amendment.

This possibility seems quite plausible in the case of the positivist argument for originalism. Under a difficult amendment procedure like Article V, constitutional text will change relatively seldom. Constitutional provisions will therefore tend to be old, and their original meaning out of step with the views of contemporary legislative majorities and the constituencies that keep them in office. In such 
circumstances, politically insulated judges might well do better than the political process at recovering and adhering to original meaning.

Under a lenient amendment procedure, by contrast, the constitutional text will change frequently, and even that text which does not change will be more closely aligned with contemporary public opinion. Otherwise, it would be overridden by amendment. In such circumstances, the views of legislative majorities and their constituents should much more closely align with original meaning than would be the case under a stringent amendment procedure like Article V. Judges, too, should have an easier time of recovering original meaning-less historical exegesis would be required - and perhaps greater inclination to do so. But the question is not simply whether judges do better than they otherwise would do, but rather how they would do relative to other decision-makers such as the legislature. And under a more lenient amendment procedure, the legislature may well do better than judges, even if legislators do not systematically or self-consciously seek original meaning. If so, judges would best fulfill their duty of adhering to positive law simply by deferring to the legislature, rather than attempting to discover original meaning themselves.

In sum, difficulty of amendment might affect interpretive choice by affecting the comparative competence of potential institutional interpreters. In the interest of brevity, we will not trace out the implications for every interpretive argument discussed in Part III. The important point is that the institutional dimension of interpretive choice does not undermine the complexity thesis. Rather, it enriches it, providing another potential source of endogeneity in the relation between difficulty of amendment and interpretive choice.

\section{The Impact of Interpretive Choice on Difficulty of Amendment}

Before closing, we also need to consider the impact of interpretive choice on difficulty of amendment. Without putting it in these exact terms, we have already considered the potential of flexible interpretation to undercut strict amendment procedures. ${ }^{103}$ We have also considered the potential of originalist approaches to effectuate such procedures. Indeed, these impacts of interpretive choice on difficulty of amendment are central to most of the endogenous arguments we discussed in Part III. There is, however, another possibility: Holding formal amendment procedures constant, interpretive choice might affect the political economy of the amendment process. More precisely, an

103 See supra Part II, 3. 
interpretive approach whose substantive content favors the politically weak at the expense of the strong will make amendment more likely (and thus, as a practical matter, easier) than one whose content does the opposite, holding formal amendment procedures constant. ${ }^{104}$

What does this imply for the complexity thesis? Once more, the strict answer is nothing. The political economy effects produced by an interpretive approach may well affect the normative desirability of that approach. Once that normative desirability is established, however, the complexity thesis applies in full force. Judges (or any other institutional interpreter) should adhere to the same interpretive approach under any amendment procedure unless the normative or empirical premises underlying that approach are endogenous to difficulty of amendment. Focusing specifically on political economy, the question is whether difficulty of amendment might alter the political-economy impacts of interpretive choice in normatively significant ways.

Consider the originalist argument from stability. Not only does originalism plausibly promote the value of stability under a difficult amendment procedure, but a difficult amendment procedure also seems likely to change the interest groups whose preferences are reflected in a stable original meaning. Exactly which interest groups might benefit is a complicated question. But suppose for the sake of argument that, under a difficult amendment procedure, original meaning will largely reflect the views of politically powerful interests. Only those interests, one might think, would be capable of overcoming the substantial hurdles of the amendment process. Conversely, under a lenient amendment procedure, a significantly broader range of interests should be able to overcome those hurdles. ${ }^{105}$

104 This basic idea underlies the familiar argument that statutory interpretation should privilege the interests of diffuse majorities over those of concentrated minorities, the latter being more readily able to obtain reversal through the political process. See, e.g., Jonathan R. Macey, Promoting Public-Regarding Legislation Through Statutory Interpretation: An Interest Group Mode, 86 COLUM. L. REV. 223 (1986); Roderick Hills, Against Preemption: How Federalism Can Improve the National Legislative Process, 82 N.Y.U. L. REV. 1 (2007). This "preference-eliciting" approach arguably explains certain canons of statutory construction, such as the rule of lenity and the presumptions against antitrust and tax exemptions. See EINER ElHAUGE: STATUTORY DEFAULT RULES: HOW TO INTERPRET UNCLEAR LEGISLATION 168-187 (2008). 105 These are not the only plausible assumptions. For example, a more difficult amendment procedure might necessitate cooperation from politically weak interests that would be unnecessary under more lenient procedures. Indeed, one key argument 
On these assumptions, the effect of originalism on the political economy of amendment is endogenous to difficulty of amendment. As the amendment procedure becomes more lenient, the content of original meaning will reflect the views of a broader - and, on average, weakerrange of interests, which in turn will render the political economy of amendment more favorable to further change. In effect, difficulty of amendment and the political economy effects of original meaning exist in a kind of feedback loop.

The upshot is that difficulty of amendment might affect interpretive choice, in part, by affecting its impact on the political economy of the amendment process. Again, in the interest of brevity, we will not trace out the implications for every interpretive argument discussed in Part III. The important point is that the political-economy effects of interpretive choice do not undermine the complexity thesis. Rather, like questions of institutional choice, they enrich it, providing another potential source of endogeneity in the relation between difficulty of amendment and interpretive choice.

\section{CONCLUSION}

The extreme difficulty of amending the U.S. Constitution plays a central but largely unexamined role in theoretical debates over interpretive choice. In particular, many scholars believe the stringency of Article $\mathrm{V}$ makes originalism less attractive. This view might ultimately be correct, but its familiarity and intuitive appeal mask substantial complexity in the relation between difficulty of amendment and interpretive choice. Increased difficulty of amendment might weaken or strengthen the case for originalism-or might be entirely orthogonal to it-depending on the goals motivating the interpretive enterprise and the empirical relation between those goals and difficulty of amendment. As we have shown, this "complexity thesis" has

in favor of supermajority rules is to protect minorities. See SCHWARTZBERG, supra note 17 at 141; see also McGinnis \& Rappaport, supra note 15 at 38-39 (arguing that supermajority processes "require consensus support to enact constitutional provisions"); Manning, supra note 83, at 1701 (arguing that the supermajority processes embedded in Article V give minorities the power "to insist upon compromise as the price of its assent"). If this is the case, it is original meaning under lenient amendment procedures that will tend to reflect the views of the politically powerful. Original meaning under difficult amendment procedures, by contrast, ought to reflect a broader social consensus. 
substantial implications for the relations between statutory and constitutional interpretation and federal and state constitutional interpretation. Perhaps most important, it highlights and clarifies the poorly understood role that difficulty of amendment plays across a range of significant interpretive debates. Without carefully attending to the normative and empirical premises underlying those debates, it is impossible to say anything of general interest about the relation between difficulty of amendment and interpretive choice. 


\section{REFERENCES}

Adam M. Samaha, Originalism's Expiration Date, 30 Cardozo L. Rev. 1295, 1300 (2008).

ADRIAN VERMEULE, JUDGING UNDER UNCERTAINTY (2006).

AlAN TARR, UnDERSTANDing STATE CONSTITUTIONS 9-10 (1998).

Alexander Aleinikoff, Updating Statutory Interpretation, 87 MicH. L. Rev. 20 (1988).

Andrew Coan, Irrelevance of Writtenness in Constitutional Interpretation, 158 U. PENN. L. ReV. 1025, 1071-83 (2010).

Andrew Coan, Talking Originalism, BYU L. Rev. 847 (2009).

Aziz Z. Huq, The Function of Article V, 162 U. PA. L. ReV. 1165, 1172 (2014).

Bruce Ackerman, The Living Constitution, 120 HARV. L. REV. 1737 (2007).

Cass R. Sunstein, Burkean Minimalism, 105 Mich. L. Rev. 353 (2006).

Cass R. Sunstein, If People Would be Outraged by Their Rulings, Should Judges Care? 60 StAN. L. Rev. 155, 167 (2007).

CAss R. Sunstein, Legal ReAsoning AND Political CONFLict 175 (1996).

Cass R. Sunstein, Of Snakes and Butterflies: A Reply, 106 Colum. L. Rev. 2234, 2236 (2006).

CASS R. SUNSTEIN, RADICALS IN ROBES: WHY RADICAL RigHT WING JUDGES ARE WRONG FOR AMERICA 74-76 (2005). 
Cass R. Sunstein, Second-Order Perfectionism, 75 FORDHAM L. REV. 2867 (2007)

Cass R. Sunstein, The Partial Constitution 100 (1993).

Cass R. Sunstein, There is Nothing that Interpretation Just Is (2014), available at $<$ http://papers.ssrn.com/sol3/papers.cfm?abstract id=2489088 $>$.

Cass R. Sunstein \& Adrian Vermeule, Interpretation and Institutions, 101 Mich. L. REV. 885, 886 (2003).

Daniel B. Rodriguez, State Constitutional Theory and Its Prospects, 28 N.M. L. REV. 271, 272 (1998)

David A. Strauss, Common Law, Common Ground, and Jefferson's Principle, 112 YALE L.J. 1717 (2003).

David A. Strauss, Common Law Constitutional Interpretation, 63 U. CHI. L. REV. 877 (1996).

David A. Strauss, The Irrelevance of Constitutional Amendments, 114 HARV. L. REV. 1457 (2001).

Debra Cassens Weiss, "How Scalia and Ginsburg Would Amend the Constitution," ABA Journal, April 21, 2014, available at http://www.abajournal.com/news/article/how scalia and ginsburg wo uld amend the constitution/.

Donald S. Lutz, Toward a Theory of Constitutional Amendment, in RESPONDING TO IMPERFECTION: THE THEORY AND PRACTICE OF CONSTitutional AMENDMENT 237 (Sanford Levinson, ed., 1995). 
Earl M. Maltz, James Gardner and the Idea of State Constitutionalism, 24 RUTGERS L.J. 1019, 1019 (1993).

Einer ElHaUge, STATUtory DeFAULt RULEs: HOW TO INTERPRET UNCLEAR LEGISLATION (2008).

EMILY ZaCKIN, LOOKING For RightS IN All the WrONG Places: WHY State Constitutions Contain AmericA's Positive Rights (2014).

ERIC A. POSNER, A Simple (and Serious) Puzzle for Originalists (Jan. 21, 2014, 2:00 AM), http://ericposner.com/a-simple-and-serious-puzzle-fororiginalists/.

Eric A. Posner \& E. Glen Weyl, Voting Squared: Quadratic Voting in Democratic Politics, 68 VAND. L. REV. (forthcoming 2015), available at $<$ http://papers.ssrn.com/sol3/papers.cfm?abstract id=2343956 $>$.

ESKRIDGE \& FEREJOHN, A RePUblic OF StATUtes: THE New AMERICAN CONSTITUTION 1-9 (2010).

Frank H. Easterbrook, Textualism and the Dead Hand, 66 GEO. WASH. L. ReV. 1119 (1998).

Gary Lawson, On Reading Recipes ... and Constitutions, 85 GEO. L.J. 1823, 1828 (1997).

Hans A. Linde, E Pluribus--Constitutional Theory and State Courts, 18 GA. L. REV. 165, 198 (1984).

Hans A. Linde, State Constitutions Are Not Common Law: Comments on Gardner's Failed Discourse, 24 RUTGERs L.J. 927, 933 (1993). 
Henry M. Hart, JR. \& Albert M. SACKS, The Legal Process: Basic PROBLEMS IN THE MAKING AND APPLICATION OF THE LAW (William N. Eskridge, Jr. \& Philip P. Frickey eds., 1994).

Herbert .L.A. HART, THE CONCEPT OF LAW (3d ed. 2012).

Jack M. Balkin, Framework Originalism and the Living Constitution, 103 NW. U. L. REV. 549 (2009).

JACK BALKIN, LIVING ORIGINALISM (2011).

Jack L. Landau, Some Thoughts About State Constitutional Interpretation, 115 PENN ST. L. ReV. 837, 838 (2011)

JAMES A. GARDNER, INTERPRETING STATE CONSTITUTIONS (2005).

James A. Gardner \& Jim Rossi, Foreword: The New Frontier of State Constitutional Law, 46 WM. \& MARY L. REV. 1231, 1232 (2005).

JAMES MAdison, The Federalist No. 49, at 313, 314 (Clinton Rossiter ed., 1961).

Jim Rossi, Assessing the State of State Constitutionalism, 109 MICH. L. ReV. 1145 (2011).

John F. Manning, The Eleventh Amendment and the Reading of Precise Constitutional Texts, 113 YALE L.J. 1663, 1693 (2004).

JOHN HART Ely, DEMOCRACY AND Distrust: A THEORY OF JUDICIAL REVIEW 11 (1980).

John O. McGinnis \& Michael B. Rappaport, Original Methods Originalism: A New Theory of Interpretation and the Case Against Construction, $103 \mathrm{Nw}$. 
U. L. REV. 751 (2009).

JOHN O. MCGINNIS \& MiCHAEL B. RAPPAPORT, ORIGINALISM AND THE GOOD CONSTITUTION (2013).

John O. McGinnis \& Michael B. Rappaport, Our Supermajoritarian Constitution, 80 TEX. L. ReV. 703 (2002)

Jonathan R. Macey, Promoting Public-Regarding Legislation Through Statutory Interpretation: An Interest Group Mode, 86 COLUM. L. REV. 223 (1986).

JULIAN Boyd, The PAPERS OF JAMES MAdisOn 392, 396 (ed., 1958).

Keith E. Whittington, Against Very Entrenched Constitutions, WISC. L. ReV. $12(2015)$

KeITH E. WhitTington, CONSTITUTIONAL INTERPRETATION: TEXTUAL MEANING, ORIGINAL INTENT, AND JUdiCiAL REVIEW 110-59 (1999).

Kent Greenawalt, Constitutional and Statutory Interpretation, in THE OXFORD HANDBOOK OF JURISPRUDENCE AND PHILOSOPHY OF LAW (Jules L. Coleman, Kenneth Einar Himma, and Scott J. Shapiro eds., 2004) 269, 289.

Kevin Stack, The Divergence of Constitutional and Statutory Interpretation, U. COLO. L. Rev 75 (2004).

Larry Alexander, Simple-Minded Originalism (San Diego Legal Studies Paper No. 08-067, 2008), available at $<$ http://papers.ssrn.com/sol3/papers.cfm?abstract id=1235722>.

Lawrence B. Solum, Communicative Content and Legal Content, 89 NOTRE DAME L. ReV. 479, 513-14 (2013). 
Lee J. Strang, Originalism and the "Challenge of Change": Abduced-Principle Originalism and Other Mechanisms by Which Originalism Sufficiently Accommodates Changed Social Conditions, 60 HASTINGS L.J. 927 (2009).

Melissa SchWARTZBERG, COUNTING THE MANY: THE ORIGINS AND LiMitS OF SUPERMAJORITY RULE 4 (2013).

Michael Klarman, Antifidelity, 70 S. CAL. L. Rev. 381 (1997).

Michael Ramsey, "Victoria Nourse on Legislative History," The Originalism Blog, February 11, 2015, at $<\underline{\text { http://originalismblog.typepad.com/the-originalism- }}$ blog/2015/02/victoria-nourse-the-constitution-and-legislative-historymichael-ramsey.html >.

Michael W. McConnell, Textualism and the Dead Hand of the Past, 66 GEO. WASH. L. REV. 1127 (1998).

Mila Versteeg \& Emily Zackin, American Constitutional Exceptionalism Revisited, 81 U. CHI. L. REV. 1641 (2014).

NeIL KOMESAR, IMPERfECt AlteRnATIVES (1994).

Paul Brest, The Misconceived Quest for Original Understanding, 60 B.U. L. REV. 204, 204-38 (1980).

Stephen M. Griffin, The Nominee is . . Article V, 12 CONST. Comment. 171 (1995).

Peter J. Smith, How Different Are Originalism and Non-Originalism? 62 HASTINGS L.J. 707, 714 (2011).

Philip A. Hamburger, The Constitution's Accommodation of Social Change, 
88 MiCH. L. REV. 239 (1989).

Philip BobbitT, CONSTitutional FATE: THEOry OF THE CONSTITUTION (1984).

Randy E. Barnett, An Originalism for Nonoriginalists, 45 LOY. L. REV. 611 (1999).

RAOUL BERGER, GOVERNMENT BY JUDICIARY: THE TRANSFORMATION OF THE FOURTEENTH AMENDMENT (1977).

Richard A. Posner, Bork and Beethoven, 42 StAN. L. ReV. 1365 (1990).

Richard A. Posner, Economics, Politics, and the Reading of Statutes and the Constitution, 49 U. CHI. L. REv. 263, 282 (1982).

RichARD A. POSNER, REFLECTIONS ON JUdGING 194 (2013).

Richard A. Primus, When Should Original Meanings Matter? 107 MicH. L. REV. 165 (2008).

Richard H. Fallon, A Constructivist Coherence Theory of Constitutional Interpretation, 100 HARV. L. REV. 1189 (1987).

Richard S. Kay, Adherence to the Original Intentions in Constitutional Adjudication: Three Objections and Responses, 82 Nw. U. L. Rev. 226, 234 (1988).

Robert A. Schapiro, Identity and Interpretation in State Constitutional Law, 84 VA. L. REV. 389, 393 (1998).

ROBERT BORK, THE TEMPTING OF AMERICA 143 (1990).

Robert F. Williams, Interpreting State Constitutions As Unique Legal Documents, 27 OKLA. CiTY U. L. REv. 189, 190 (2002). 
Robert G. Dixon, Jr., Article V: The Comatose Article of Our Living Constitution?, 66 MicH. L. REV. 931 (1968).

Roderick Hills, Against Preemption: How Federalism Can Improve the National Legislative Process, 82 N.Y.U. L. REV. 1 (2007).

RONALD DWORKIN, LAW's EMPIRE (1986).

RONALD DWORKIN, TAKING RIGHTS SERIOUSLY (1978).

Rosalind Dixon \& Richard Holden, Constitutional Amendment Rules: The Denominator Problem, COMPARATIVE CONSTITUTIONAL DESIGN 195 (Tom Ginsburg ed., 2012).

SANFORD LEVINSON, FRAMED: AMERICA's 51 CONSTITUTIONS AND THE CRISIS OF GOVERNANCE (2012).

Stanley Fish, Interpretation is All There Is: A Critical Analysis of Aharon Barak's Purposive Interpretation in Law, 29 CARDOZO L. REV. 1109, 1112 (2008).

Stephen E. Sachs, Originalism as a Theory of Legal Change (2014), HARV. J.L. \& PUB. POL'Y (forthcoming), available at $<$ http://papers.ssrn.com/sol3/papers.cfm?abstract id=2498838 $>$.

Stephen Holmes, Precommitment and the Paradox of Democracy, in CONSTITUTIONALISM AND DEMOCRACy 195 (Jon Elster \& Rune Slagstad eds., 1988).

Steven G. Calabresi \& Hannah M. Begley, Originalism and Same Sex Marriage (October 13, 2014). Northwestern Public Law Research Paper 
No. 14-51. Available at SSRN: $<\underline{\text { http://ssrn.com/abstract }=2509443}>$ or

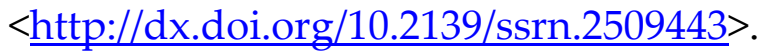

Steven G. Calabresi \& Julia Rickert, Originalism and Sex Discrimination, 90 TeX. L. ReV. 1 (2011).

Steven P. Lalley \& E. Glen Weyl, Quadratic Voting (2015), available at $<$ http://papers.ssrn.com/sol3/papers.cfm?abstract id=2003531 $>$.

Terrance Sandalow, Constitutional Interpretation, 79 MiCH. L. REv. 1033, 1046 (1981).

Vijay Krishna \& John Morgan, Majority Rule and Utilitarian Welfare (2012), AM. ECON. J.: MiCROECONOMICS (forthcoming), available at $<$ http://papers.ssrn.com/sol3/papers.cfm?abstract id=2083248 $>$.

William Baude, Is Originalism Our Law?, COLUM. L. REv. (forthcoming 2015) (on file with author).

William N. Eskridge, Dynamic Statutory Interpretation, 135 U. PA. L. REV. 1479, 1496 (1987).

William Eskridge, No Frills Textualism, 119 HARV. L. REV. 2041, 2045-46 (2006).

ZaChary ElKins, TOM GINSBURG \& JAMES MELTON, THE ENDURANCE OF NATIONAL CONSTITUTIONS (2009).

Difficulty of Amendment and Interpretative Choice Dificuldade para Emendar e Escolha Interpretativa Submitted: 2015-11-30 Accepted: 2015-12-27 